\title{
A Phenomenographic Study on Views About Entertaining and Boring Situations in Learning Process
}

\author{
Esen Turan-Özpolat ${ }^{1}$ \\ ${ }^{1}$ School of Education, Adiyaman University, Adiyaman, Turkey \\ Correspondence: Esen Turan-Özpolat, School of Education, Adiyaman University, Adiyaman, 02040 Merkez, \\ Turkey. E-mail: esen.turan@hotmail.com
}

Received: February 17, 2020

Accepted: July 2, $2020 \quad$ Online Published: September 21, 2020

doi:10.5539/ies.v13n10p8

URL: https://doi.org/10.5539/ies.v13n10p8

\begin{abstract}
In the learning process, it is accepted that learning with entertainment is important in participation in the process and retention of learning. Thus, the aim of the present study was to investigate the views of students and teachers on entertaining and boring settings in the learning process. Phenomenography method was used in the study. The study group included fourth grade teachers and students in public and private schools in Adiyaman province central district in Turkey. In this context, seven schools, four private and three public schools, were selected among the schools, where students of the parents with different socio-economic background attended, with purposive sampling method. A total of 10 primary school 4th grade teachers employed these schools participated in the study on a voluntary basis. The study group included 80 students. Individual and focus group interview and photointerviewing techniques were used in data collection Data were analyzed with content analysis method. In the study, it was concluded that teachers and students liked similar class settings and both teachers and students liked classrooms that were furnished with sufficient number of tools and equipment, heating and lighting, where colorful and plenty of activities could be conducted and equipped with technological tools. Furthermore, it was determined that the teachers and students criticized the photographs they disliked due to the lack of facilities in the classroom to implement different methods, similarities with their own classrooms, or for being dark and old-looking, and the unhappy demeanor of the students and teachers on the photographs. The study findings were discussed and interpreted within the framework of the literature.
\end{abstract}

Keywords: learning process, entertainment, teacher, student, phenomenography

\section{Introduction}

Entertainment, which could be defined as enjoyable and joyful (Turkish Language Institution [TLI], 2015), makes life a pleasure, enlivens it and helps eliminate the troubles in life a little when it happens. Furthermore, entertainment could include the comforting and happy moments that humankind may need in almost every moment in life, especially during ordinary, tiring or boring times. In fact, Zillmann (2000, cited by Cakir, 2005, p. 124) stated that the current age is an age of entertainment as well as an age of information, and all the capacity of the production, change and transfer of information serves entertainment as much as or perhaps more than businesses. It would not be strange to think that integration of the concept of entertainment that is considered universal and significant with learning, which is as much universal and significant in human life, would be beneficial. Ozdemir (2001, p. 256) stressed the role of entertainment in learning as follows: Entertainment and enjoyable learning is essential for the commitment of a student to life-oriented education. When there is pleasure and entertaining in learning, the required efforts would not be a burden. Furthermore, several educators use the concept of "the pleasure of learning" synonymous with "entertainment, satisfaction, and play" (Al-shara, 2015). Moreover, in a study by Memnun and Akkaya (2010), it was reported that most students in primary education liked to learn through games and activities, and the game-based instruction method could be used to make the classes more entertaining.

Several studies reported that student participation and achievement would increase in an entertaining learning environment created by various activities (Akengin \& Ibrahimoglu, 2010; Barata, Gama, Jorge, \& Goncalves, 2013; Brewer, Anthony, Brown, Irwin, Nias, \& Tate, 2013; Campbell, 2012; Erdem, 2015; Goehle, 2013; Guler, Cakmak, \& Kavak, 2013; Kapp, 2012; Raymer, 2011; Stupiansky, Stupiansky, \& Nicholas, 1999; Tural, 2005; Vernon, 2009). In fact, it was reported that learning is enforced by high student participation (Akinoglu, 2004; 
Bloom, 1976; Crouch, Fagen, Callan, \& Mazur, 2004).

The learning activities that could be considered as entertainment include educational games (Erdem, 2015; Yildirim, 2016), educational movies and music (Gencel-Ataman, 2014), painting, dancing, cartoons (Erdem, 2015; Guler, Cakmak, \&, Kavak, 2013), humor (Asilioglu, 2013; Cornett; 1986; Elias, 2015; Huang, Liu, Lai, \& Liu, 2017; Wagner \& Urios-Aparisi, 2011), various funny and educational stories and rhetoric, riddles, jokes, proverbs (Gocer, 2010), and drama (Heathcote \& Bolton, 1994). Among these activities, games have playful and relaxing properties. It was also reported that the games increase the sharing and collaboration among children as it provides a voluntary environment for discussion and participation in the process (Erdem, 2015, p. 41). In brief, several behavior, knowledge and skills that the child requires are acquired through games (Tezel-Sahin, Balci, Aydin-Kilic, \& Yazar, 2015, p. 299). In the learning process, the games could be included in a simple conventional format, as well as through the digital tools which are commonly used in the information age. Erdal (2012, p. 56) reported the various effects of music on human development based on the approach of Montessori that "music leads to physical, intellectual and emotional development" in a study on the role of music instruction methods in preschool education according to developmental and learning theoreticians. Gencel-Ataman (2014) stated in her study titled that music was quite significant for mental, spiritual and cultural development of humans and music was effective on achievements in the mathematics course. Painting activities are generally included in the activities utilized in free activity courses in addition to its own course content (Visual Arts) (Ay, Acat, \& Yuksel, 2016; Aydin, Bakirci, \& Urey, 2012; Bektas \& Dincer, 2011; Bozpolat, 2016; Dundar \& Karaca, 2011; Gultekin, Atalay, \& Ay, 2014) and this is due to its relaxing and soothing properties (Ferahoglu, Tepecik, \& Kalyoncu, 2014; Kalyoncu \& Liman, 2013; Ozturk, Peker, \& Gokdas, 2017). Akengin and Ibrahimoglu (2010, p.2) emphasized the significance of the use of cartoons in education and stated that these activities do only aim to make the audience smile, but to make them think as well. Thus, it is obvious that cartoons should be included in current education approaches where learning is targeted and focused on thinking. It has been always suggested that the use of humor in instruction has beneficial effects (Bryant, Comisky, Crane, \& Zillmann, 1980; Chabeli, 2008; Kaya, 2011; Ozkan, 2008; Sidekli, Er, Yavaser, \& Aydin, 2014). According to Quina (1989), when students laugh with their teachers, they generally prefer to collaborate. Because the joy of teachers in teaching often increases with their enthusiasm in their practices. When students observe this enthusiasm, their enjoyment levels also increase (Witt, Wheeless, \& Allen, 2004).

Recently, various concepts and learning approaches have come to the forefront that advocate that games, pleasant moments, and thus more entertainment should be included in learning processes. These concepts and approaches include the concept of entertaining learning (Education Information Network [EIN], 2018; Learning with Fun, 2018; Teach Thought, 2017), game based learning approach (Bakhsh, 2016; Chang, Warden, Liang, \& Lin, 2018; Dickey, 2011; Turan-Guntepe \& Donmez-Usta, 2017) and gamification approach (Caponetto, Earp, \& Ott, 2014; Kim, Song, Lockee, \& Burton, 2018; Yildirim, 2016), and these are included in various studies, books and databases and their significance in the learning process was emphasized.

In addition to entertainment, boredom and getting bored are also widely accepted concepts in the learning process. If the course is teacher-centered and if the students are not active in the class and could not comprehend the topic, if the course is not entertaining, if the instruction techniques are conventional or the physical classroom conditions are not adequate, it is possible that the students would be bored in classroom. Several studies were conducted on this topic (Al-Shara, 2015; Arai, 2004; Baba-Khouya, 2018; Delpech, 2002; Ersoy, 2016; Koca-Ozgun \& Sen, 2006; Memnun \& Akkaya, 2010; Prokop, Prokop, \& Tunnicliffe, 2007; Sakai \& Kikuchi, 2009; Tranter, 2004). In a study on student boredom in classroom, Mann and Robinson (2009) reported that $59 \%$ of the students found half of the time they spent in the classroom boring and 30\% found the courses mostly boring. Thus, it was stated that more than one fourth of these students take a break in the middle of the process. The factors that lead to boredom in the classroom were determined as widespread use of conventional instruction techniques and PowerPoint presentations. In the same study, it was reported that students adopt various strategies to cope with boring classes, while the most popular strategies included daydreaming, doodling, chatting with friends and writing notes to friends.

Thus, the present study aimed to determine entertaining and boring conditions in learning process based on the views of students and teachers. Furthermore, the study aimed to develop ideas and recommendations to increase the entertaining periods and reduce boring periods in the learning process, and thus to take various measures in order to create environments where the learning process could be maintained with success. Moreover, the present study is considered significant since it is the first study on this topic using this methodology in Turkey. 


\section{Method}

Entertainment and boring are the phenomena. So phenomenography, a qualitative method, was used in the study. Phenomenography is a research method that tackles the perceptions, understanding and experiences of individuals about the phenomena they experience in the universe. However, it is not necessary to deal with a special case as in phenomenology, but the determination of the perceptions of the individuals is important in phenomenography. While there are variations between the perceptions of the phenomenon which is the subject of research in phenomenography, in phenomenology, the aim is to determine the presence and the essence of the investigated phenomenon (Cekmez, Yildiz, \& Tumer, 2012). Phenomenography, therefore, is related to how different individuals perceive and think about the same phenomenon.

\subsection{Study Group}

The study group included primary school 4th grade teachers and students in public and private schools in the central district of Adiyaman province at the end of the 2016-2017 academic year fall semester. In this context, there are a total of seven schools, four of which are private and three are public schools, which were determined with purposive sampling method among the schools with parents in different socio-economic classes. In the study, 10 primary school fourth grade teachers, one from each private school and two from each public school, participated on a voluntary basis. The students in the study group included one student from the classes of the participating teachers in two private schools and three public schools. The total number of students included in the study was 80 .

The fact that the study data had to be collected on the last week of the semester decreased the number of $4^{\text {th }}$ grade students who could participate in the study and became a limitation for the study. The researcher obtained the approval of school administrators to conduct and record interviews with the teachers and students in that school and then made appointments with the participating teachers. All interviews were conducted in designated schools during the appointments. Information about schools, students and teachers is presented in Table 1.

Table 1. Distribution of the schools and participating teachers

\begin{tabular}{|c|c|c|c|c|}
\hline School Type & School & Gender & Total \# of Teachers (f) & Seniority (years) \\
\hline Private & Birey Primary School & Female & 1 & 28 \\
\hline Private & Doruk Primary School & Male & 1 & 39 \\
\hline Private & Ikra Primary School & Female & 1 & 29 \\
\hline Private & Simya Primary School & Male & 1 & 12 \\
\hline \multirow{2}{*}{ Public } & \multirow{2}{*}{ Borsa İstanbul Primary School } & Male & 1 & 2 \\
\hline & & Male & 1 & 38 \\
\hline \multirow{2}{*}{ Public } & \multirow{2}{*}{ Menderes Primary School } & Female & 1 & 11 \\
\hline & & Male & 1 & 18 \\
\hline \multirow{2}{*}{ Public } & \multirow{2}{*}{ Tekel 75. Yil Primary School } & Female & 1 & 22 \\
\hline & & Female & 1 & 28 \\
\hline & Total & $\begin{array}{c}5 \text { Females } \\
5 \text { Males }\end{array}$ & 10 & $\begin{array}{c}\text { 1-10 years; } 1 \text { teacher } \\
11-20 \text { years; } 3 \text { teachers } \\
21-30 \text { years; } 4 \text { teachers } \\
31 \& \text { more years; } 2 \text { teachers }\end{array}$ \\
\hline
\end{tabular}

In Table 1, it can be observed that the number of female and male teachers was equal ( 5 females, 5 males). Teacher seniority varied between 2 and 39 years. Furthermore, it was observed that the teacher seniority was mostly between 11-30 years. 
Table 2. Distribution of the schools and participating students

\begin{tabular}{cccccc}
\hline School Type & School & Female Students & Male Students & Total \# of Students (f) & $\%$ \\
\hline \multirow{4}{*}{ Private } & Birey Primary School & - & 12 & 12 & 15 \\
\cline { 2 - 6 } & Simya Primary School & 6 & 4 & 10 & 12.5 \\
\cline { 2 - 6 } & Total & 6 & 16 & 22 & 27.5 \\
\hline \multirow{3}{*}{ Public } & Borsa İstanbul Primary School & 13 & 7 & 20 & 25 \\
\cline { 2 - 6 } & Menderes Primary School & 10 & 3 & 13 & 16.25 \\
\cline { 2 - 6 } & Tekel 75. Yil Primary School & 16 & 9 & 25 & 31.25 \\
\hline \multirow{2}{*}{ Grand Total } & Total & 39 & 19 & 58 & 72.5 \\
\hline
\end{tabular}

Table 2 demonstrates that the number of female and male students was close, however the number of female students $(n=45)$ was higher than that of male students $(n=35)$. Furthermore, it could be observed that the number of students attending public schools $(n=58,72.5 \%)$ was higher than the number of students attending private schools $(\mathrm{n}=22,27.5 \%)$.

\subsection{Data Collection}

The interview technique was used in the data collection process. In addition to individual and focus group interview techniques, the photointerviewing technique was also used since the researcher considered that it would deepen and enrich the study data. In a recent study on photointerviewing technique, which has been increasingly used in research, Uygun (2011, p. 45) stated that the technique involves showing photos to the participants and asking them to comment on what they see in the picture and to narrate a story.

In individual interviews (conducted with teachers) and focus group interviews (conducted with students), the participants were asked semi-structured questions on entertaining and boring school and classroom environments. In addition to these questions, photographs of classrooms taken in various countries were shown to the participants within the context of photointerviewing technique and they were asked to narrate their views on these photographs and in which classroom they wanted to be in and why. The replies to all questions and statements about the photographs were recorded using a voice recorder. Photographs included classroom pictures from the Ivory Coast, Finland and the USA based on their differences in socio-economic, education and developmental levels. However, the information about the countries was not shared with the participants during the interview in order to prevent the effects of possible prejudices.

In line with the aim of the study, a total of six semi-structured interview questions were posed to teachers and students. The face-to-face interviews conducted with the teachers lasted about 15-20 minutes and the focus group interviews conducted with students from 5 classes lasted approximately 40 minutes each. The questions included in the interviews conducted with the teachers were as follows:

1) Is your classroom entertaining or boring? Why?

2) How would you describe a boring classroom environment?

3) What do you do to make the classroom environment more entertaining? (Physically and visually)

4) What do you do to make the lesson more entertaining? (Based on the instruction, methodology, material or evaluation)

5) In which setting depicted in the photographs (Photo 1, Photo 2, Photo 3) you would like to instruct?

6) What are your views on the classroom environments depicted in the photographs? 


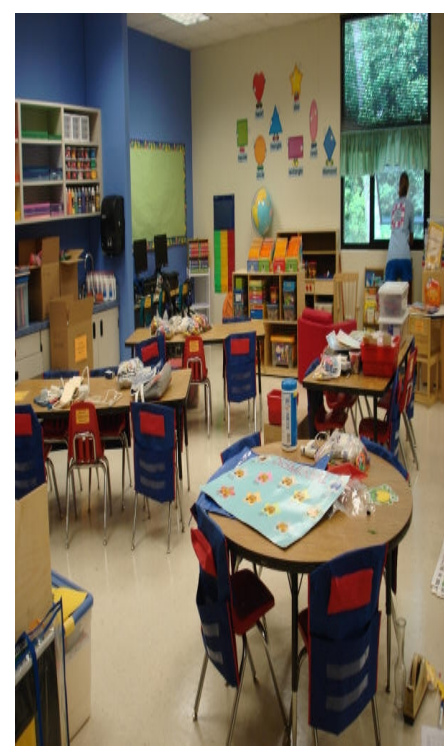

Photo 1 (Finland)

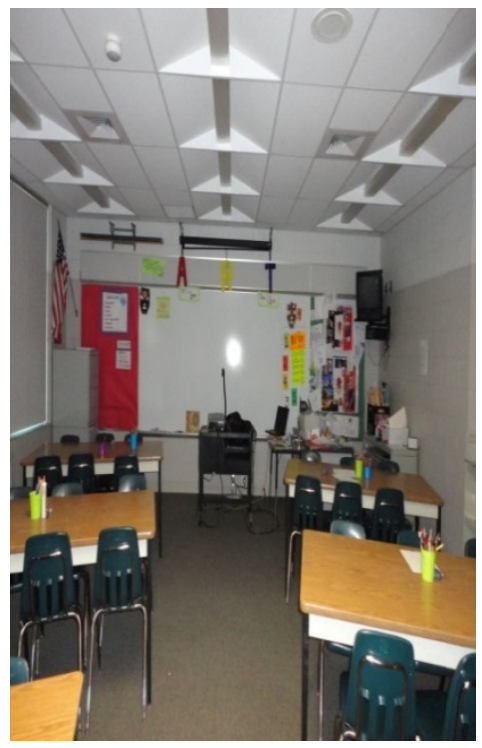

Photo 2 (USA)

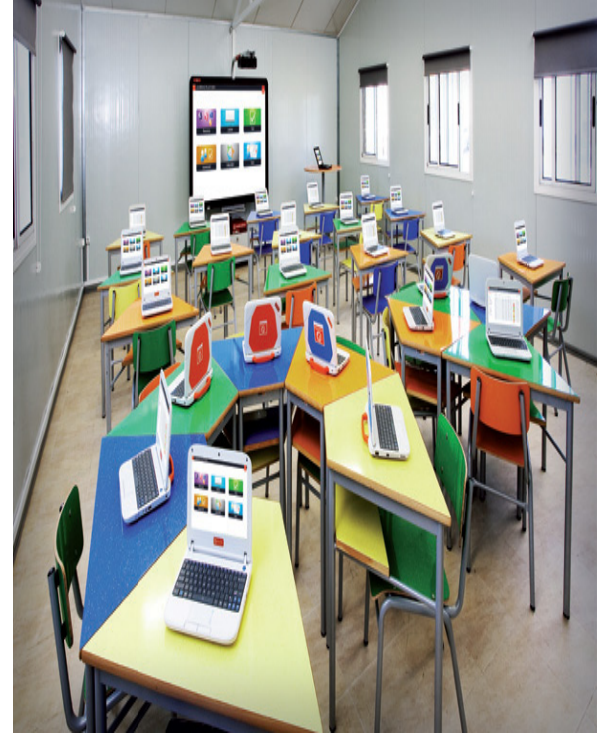

Photo 3 (Finland/technological)

The questions included in the interviews conducted with the students were as follows:

1) Is your classroom entertaining or boring? Why?

2) How would you describe a boring classroom environment?

3) How would you describe an entertaining classroom environment?

4) What does your teacher do in the classroom to make it more entertaining or likable?

5) In which setting depicted in the photographs (Photo 1, Photo 2, Photo 3) you would like to be instructed?

6) What are your views on the classroom environments depicted in the photographs?

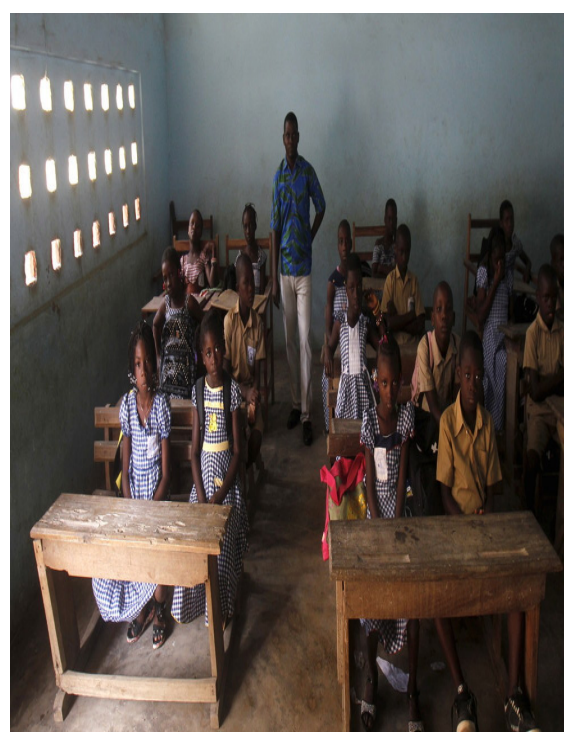

Photo 1 (Ivory Coast)

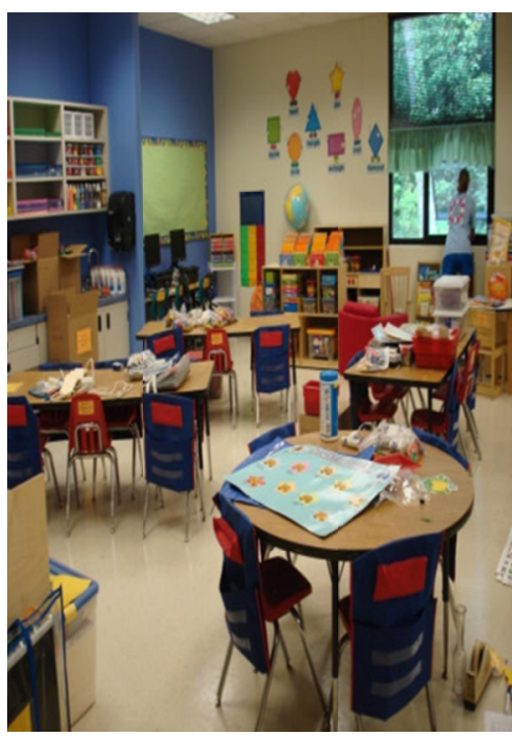

Photo 2 (Finland)

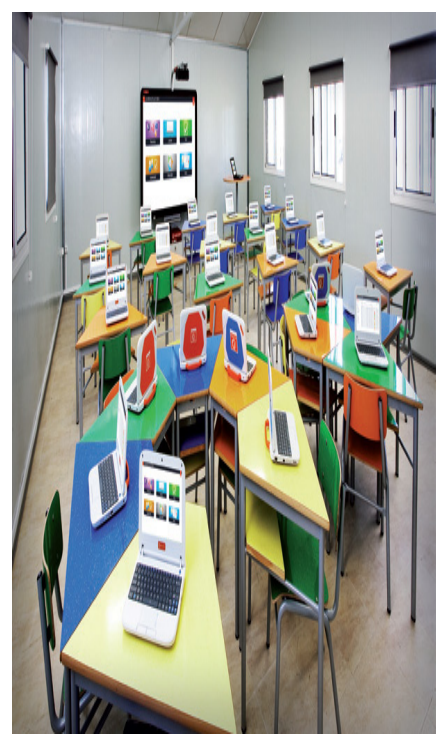

Photo 3 (Finland/technological)

\subsection{Data Analysis}

The data obtained by transcribing the recordings were analyzed with the content analysis method. In the analysis process, data was classified under main themes, themes and categories. Thus, data frequencies and percentages 
were also presented. On determination of these classifications, the data were checked by the researcher and a specialist and the statements on which there was an agreement were included in the main themes, themes and categories.

\subsection{Validity and Reliability}

In the study, both the interview questions and the photographs were determined to serve the aim of the study, and a literature review was conducted and views of two field experts were obtained to ensure the content validity. Internal validity in terms of construct validity was provided by clear and detailed presentation of data collection and analysis processes and study findings. The external validity was obtained by the fitness of the study group, the study environment and clear identification of these settings.

During the analysis of the data collected in the interviews, a field expert and the author calculated the reliability of the study. This calculation was conducted with the formula developed by Miles and Huberman (1994) (Reliability $=$ Agreement/(Agreement + Disagreement $\mathrm{x}$ 100). The present study was considered reliable since the reliability coefficient was calculated as $86 \%$ and exceeded the $70 \%$ limit.

\section{Findings}

The findings obtained with the interviews conducted with the study groups are presented in the present section. Thus, initially, the findings obtained with the interviews conducted with the teachers, and then the findings obtained with the interviews conducted with the students are presented. The tables that included the findings and the interpretation of these tables are also included in this section.

\subsection{Findings Obtained with the Interviews Conducted with the Teachers}

The views of the teachers on the entertaining or boring status of their classroom during the learning process, an entertaining class environment, and a boring class environment are presented in this sub-section. Furthermore, the physical and visual contributions, instructional efforts of teachers to make the class environment entertaining, the classroom(s) in the photograph(s) where they desired to instruct and their views on the class environments in the photographs are also included. Each finding is presented under related sub-heading.

\subsubsection{The Teacher Views on Whether Their Classroom was Entertaining or Boring}

Table 3. General teacher views on whether their classroom was entertaining or boring

\begin{tabular}{lcc}
\hline Main Themes & F & $\%$ \\
\hline Sometimes entertaining, sometimes boring & 5 & 50 \\
Entertaining & 4 & 40 \\
Boring & 1 & 10 \\
Total & 10 & 100 \\
\hline
\end{tabular}

Half of the teachers $(50 \%)$ considered that their classes were sometimes entertaining, sometimes boring. Nearly half $(40 \%)$ of considered think their classes entertaining, while very few (10\%) considered their classes boring. As seen, teachers mainly considered that their classes were entertaining.

Table 4. The views of the teachers which implied that their classroom was entertaining

\begin{tabular}{|c|c|c|c|c|}
\hline Main Theme & Theme & Category & $\mathrm{F}$ & $\%$ \\
\hline \multirow{12}{*}{$\begin{array}{c}\text { Class is } \\
\text { entertaining }\end{array}$} & & & & 15.47 \\
\hline & With respect to the student & The students participate in the instruction & 4 & 15.2 \\
\hline & \multirow{6}{*}{ With respect to the teacher } & My approach is empathetic & 2 & 7.7 \\
\hline & & I try to simulate a domestic environment in the class & 2 & 7.7 \\
\hline & & I instruct the course at a happy place & 1 & 3.8 \\
\hline & & I consider the students as my own children and I love them so much & 1 & 3.8 \\
\hline & & We have a daily feeding time & 1 & 3.8 \\
\hline & & Total & 7 & 26.9 \\
\hline & \multirow{4}{*}{ With respect to instruction } & We dramatize the topics & 3 & 11.5 \\
\hline & & Instruction includes games & 2 & 7.7 \\
\hline & & We pop corn and watch movies & 1 & 3.8 \\
\hline & & We organize the program based on the students & 1 & 3.8 \\
\hline
\end{tabular}




\begin{tabular}{ccc}
$\begin{array}{c}\text { I ask questions based on the student interests and make the topics more } \\
\text { interesting }\end{array}$ & 1 & 3.8 \\
\hline We instruct by living-doing & 1 & 3.8 \\
\hline We provide several examples from daily life & 1 & 3.8 \\
\hline There are additional etude hours & 1 & 3.8 \\
\hline We conduct painting activities & 1 & 3.8 \\
\hline I use humor (jokes, etc.) & 1 & 3.8 \\
\hline We conduct plenty of activities & 1 & 3.8 \\
\hline We organize trips & 1 & 3.8 \\
\hline Total & 15 & 57.7 \\
\hline Grand Total & 26 & 100
\end{tabular}

Most teachers who considered that their classes were entertaining (57.7\%) considered their classes entertaining with respect to instruction, some $(26.9 \%)$ considered their classes entertaining with respect to teachers and less (15.2) considered their classes entertaining with respect to the students.

Table 5. The views of the teachers which implied that their classroom was boring

\begin{tabular}{|c|c|c|c|c|}
\hline Main Theme & Theme & Category & $\mathrm{F}$ & $\%$ \\
\hline \multirow{13}{*}{$\begin{array}{l}\text { Class is } \\
\text { boring }\end{array}$} & \multirow{4}{*}{ With respect to the student } & Lack of participation & 3 & 23.1 \\
\hline & & The class is crowded (preventing entertaining) & 2 & 15.4 \\
\hline & & Repetition of previously instructed topics & 1 & 7.7 \\
\hline & & Total & 6 & 46.2 \\
\hline & With respect to the teacher & Continuous direct instruction & 1 & 7.7 \\
\hline & \multirow{4}{*}{ With respect to the school } & Lack of facilities at school & 1 & 7.7 \\
\hline & & Heating problem & 1 & 7.7 \\
\hline & & Lack of classroom cleaning & 1 & 7.7 \\
\hline & & Total & 3 & 23.1 \\
\hline & \multirow{4}{*}{$\begin{array}{l}\text { With respect to the education } \\
\text { system }\end{array}$} & It is boring during pilot exams due to competition & 1 & 7.7 \\
\hline & & $\begin{array}{l}\text { Disorder in the class due to sharing the classroom with the morning shift } \\
\text { (sitting order, board, etc.) }\end{array}$ & 1 & 7.7 \\
\hline & & Parental intervention to the instruction method & 1 & 7.7 \\
\hline & & Total & 3 & 23.1 \\
\hline & & Grand Total & 13 & 100 \\
\hline
\end{tabular}

Teachers, who stated that their classes were boring, considered the case mostly $(46.2 \%)$ with respect to the students, then with respect to the school and education system in equal rates $(23.1 \%)$, and the least in terms of teachers $(7.7 \%)$.

\subsubsection{The Teacher Views on the Design of the Entertaining or Boring Class Environment}

Table 6. Teacher views on the design of the entertaining or boring class environment

\begin{tabular}{|c|c|c|c|c|}
\hline Main Theme & Theme & Category & $\mathrm{F}$ & $\%$ \\
\hline \multirow{11}{*}{$\begin{array}{c}\text { An entertaining classroom } \\
\text { design }\end{array}$} & \multirow{9}{*}{$\begin{array}{l}\text { With respect to } \\
\text { instruction }\end{array}$} & Should provide plenty of game facilities & 2 & 3.9 \\
\hline & & Teachers should be affectionate & 1 & 1.9 \\
\hline & & Various instructional methods should be used & 1 & 1.9 \\
\hline & & Jokes should be utilized & 1 & 1.9 \\
\hline & & Riddles should be utilized & 1 & 1.9 \\
\hline & & Puzzles should be included & 1 & 1.9 \\
\hline & & Cartoons should be included & 1 & 1.9 \\
\hline & & Class size should be reduced & 1 & 1.9 \\
\hline & & Total & 9 & 17.6 \\
\hline & \multirow{2}{*}{ With respect to material } & Required material should be available & 4 & 7.8 \\
\hline & & Materials should be interesting & 2 & 3.9 \\
\hline
\end{tabular}




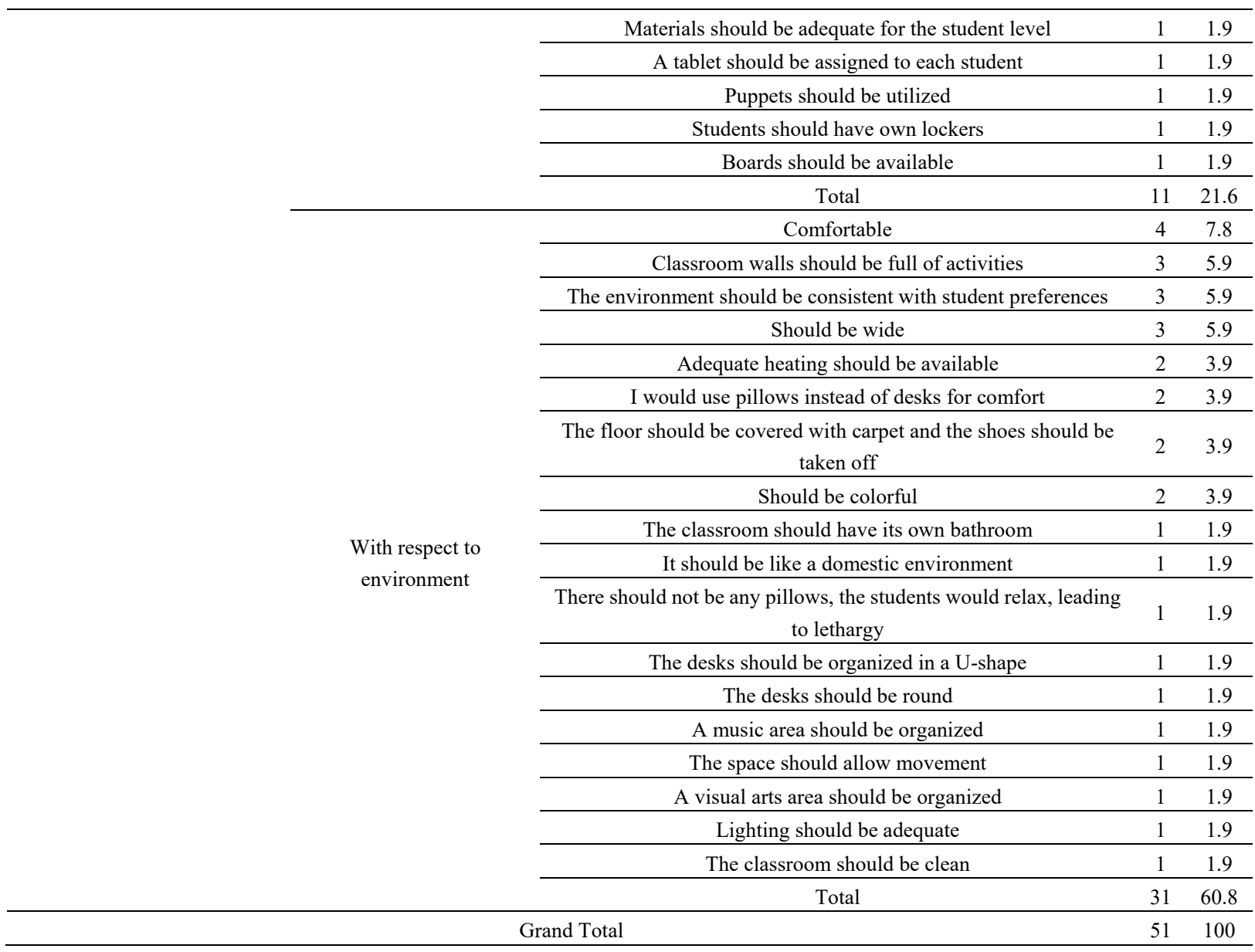

The teachers indicated an entertaining classroom environment design mostly $(60.8 \%)$ with respect to the environment, then $(21.6 \%)$ with respect to material, and at least, with respect to instruction (17.6\%).

\subsubsection{The Teacher Views on the Design of a Boring Class Environment}

Table 7. Teacher views on the design of a boring class environment

\begin{tabular}{|c|c|c|c|c|}
\hline Main Theme & Theme & Category & $\mathrm{F}$ & $\%$ \\
\hline \multirow{17}{*}{$\begin{array}{l}\text { Boring classroom } \\
\text { design }\end{array}$} & \multirow{3}{*}{ With respect to students } & Non-participation & 8 & 20 \\
\hline & & Unprepared attendance & 1 & 2.5 \\
\hline & & Total & 9 & 22.5 \\
\hline & \multirow{13}{*}{ With respect to teachers } & Teacher-oriented education & 4 & 10 \\
\hline & & Non-inclusion of various instruction methods & 2 & 5 \\
\hline & & Ignorance of children's interests, their world & 2 & 5 \\
\hline & & Non-suitability of the course topics to student readiness level & 1 & 2.5 \\
\hline & & Non-inclusion of games & 1 & 2.5 \\
\hline & & Low number of activities & 1 & 2.5 \\
\hline & & Non-colorful & 1 & 2.5 \\
\hline & & Too much noise & 1 & 2.5 \\
\hline & & $\begin{array}{l}\text { Instruction of the course by the teacher with a similar and monotonous } \\
\text { tone without articulation }\end{array}$ & 1 & 2.5 \\
\hline & & Ignorance of children's attention span & 1 & 2.5 \\
\hline & & Lack of teacher-student communication & 1 & 2.5 \\
\hline & & An oppressive environment & 1 & 2.5 \\
\hline & & Total & 17 & 42.5 \\
\hline & With respect to school & Lack of material-equipment & 4 & 10 \\
\hline
\end{tabular}




\begin{tabular}{|c|c|c|c|}
\hline \multirow[t]{6}{*}{ administration } & Crowded classes (inefficient activities) & 4 & 10 \\
\hline & Inadequate classroom temperature & 2 & 5 \\
\hline & Uncomfortable classroom & 1 & 2.5 \\
\hline & Narrow classroom & 1 & 2.5 \\
\hline & Dark classroom & 1 & 2.5 \\
\hline & Dirty classroom & 1 & 2.5 \\
\hline \multicolumn{2}{|r|}{ Total } & 14 & 35 \\
\hline \multicolumn{2}{|r|}{ Grand Total } & 40 & 100 \\
\hline
\end{tabular}

When teachers indicated the design of a boring classroom environment, they mostly emphasized teacher-related issues $(42.5 \%)$, followed by issues related to the school administration (35\%) and finally, by issues related to the students $(22.5 \%)$.

\subsubsection{The Teacher Views on Their Physical and Visual Efforts to Make Classroom Environment Entertaining}

Table 8. The teacher views on their physical and visual efforts to make classroom environment entertaining

\begin{tabular}{|c|c|c|c|c|}
\hline Main theme & Theme & Category & $\mathrm{F}$ & $\%$ \\
\hline \multirow{17}{*}{$\begin{array}{l}\text { Physical and visual } \\
\text { efforts }\end{array}$} & \multirow{7}{*}{ I cannot do anything } & Since all my students are male, I cannot color and hang activities, etc. & 1 & 5.3 \\
\hline & & Lack of material & 1 & 5.3 \\
\hline & & The desks are in a row and two children use a desk & 1 & 5.3 \\
\hline & & The desks are not comfortable & 1 & 5.3 \\
\hline & & $\begin{array}{l}\text { There are only a few boards and we share them with the morning shift, } \\
\text { they are not effective }\end{array}$ & 1 & 5.3 \\
\hline & & $\begin{array}{l}\text { The boards are hung at higher points on the wall and the textual or picture } \\
\text { activities are illegible }\end{array}$ & 1 & 5.3 \\
\hline & & Total & 6 & 31.6 \\
\hline & \multirow{6}{*}{ I provide comfort } & I adjust the temperature and lighting in the classroom & 2 & 10.5 \\
\hline & & Each student has own locker & 2 & 10.5 \\
\hline & & I clean the classroom & 1 & 5.3 \\
\hline & & We maintain the order in the classroom & 1 & 5.3 \\
\hline & & The desks are adequate for the class size & 1 & 5.3 \\
\hline & & Total & 7 & 36.8 \\
\hline & \multirow{4}{*}{$\begin{array}{l}\text { I provide an active study } \\
\text { environment }\end{array}$} & We have a library & 2 & 10.5 \\
\hline & & We create boards & 2 & 10.5 \\
\hline & & $\begin{array}{l}\text { I move everyone to the subsequent desk every week (to prevent the } \\
\text { passivism of the students sitting at the back) }\end{array}$ & 1 & 5.3 \\
\hline & & We exhibit experiment results at a section in the class & 1 & 5.3 \\
\hline & & Total & 6 & 31.6 \\
\hline & & Grand Total & 19 & 100 \\
\hline
\end{tabular}

The teachers expressed the physical applications they implemented to make the classroom entertaining as "I provide comfort" the most (36.8\%), followed by "I provide an active study environment (31.6\%) and "I cannot do anything" (31.6\%).

\subsubsection{The Teacher Views on Their Instructional Efforts to Make Classroom Environment Entertaining}

Table 9. The teacher views on their instructional efforts to make classroom environment entertaining

\begin{tabular}{ccccc}
\hline Main Theme & Theme & Category & $\mathrm{F}$ & $\%$ \\
\hline & & Playing games & 7 & 9.1 \\
\cline { 3 - 5 } & & Drama & 6 & 7.8 \\
\cline { 3 - 5 } Instructional Efforts & \multirow{2}{*}{ Doing-Living } & Experiments-applications & 4 & 5.2 \\
\cline { 3 - 5 } & & Hanging the poetry they wrote or paintings they painted on the board & 4 & 5.2 \\
\cline { 2 - 5 } & & Dancing & 2 & 2.6 \\
\cline { 2 - 5 }
\end{tabular}




\begin{tabular}{|c|c|c|c|}
\hline & Instructing the physical education course at the school piscine for 1 hour every week & 1 & 1.3 \\
\hline & Total & 24 & 31.2 \\
\hline \multirow{4}{*}{ Audiovisual } & Watching movies/videos & 7 & 9.1 \\
\hline & Active smart board use & 6 & 7.8 \\
\hline & Chatting with puppets & 3 & 3.9 \\
\hline & Total & 16 & 20.8 \\
\hline \multirow{5}{*}{ Visual } & Drawing cartoons on the board & 3 & 3.9 \\
\hline & Solving puzzles & 2 & 2.6 \\
\hline & Conducting painting activities & 1 & 1.3 \\
\hline & Marbling (at painting workshop) & 1 & 1.3 \\
\hline & Total & 7 & 9.1 \\
\hline \multirow{7}{*}{ Auditory } & Telling jokes & 6 & 7.8 \\
\hline & Joking & 6 & 7.8 \\
\hline & Singing & 3 & 3.9 \\
\hline & Telling riddles & 3 & 3.9 \\
\hline & Reading poetry & 1 & 1.3 \\
\hline & Chatting on various topics & 1 & 1.3 \\
\hline & Total & 20 & 26 \\
\hline \multirow{4}{*}{ Intellectual } & Asking entertaining and interesting questions & 2 & 2.6 \\
\hline & Brainstorming & 1 & 1.3 \\
\hline & Conducting numerical activities & 1 & 1.3 \\
\hline & Total & 4 & 5.2 \\
\hline \multirow{3}{*}{ General } & I use various methods based on multiple intelligence program & 1 & 1.3 \\
\hline & I utilize Internet software such as EIN, Okulistik and Morpa etc. for topic details & 1 & 1.3 \\
\hline & Total & 2 & 2.6 \\
\hline \multirow{3}{*}{ Psychological } & I reward achievements or good behavior with stars/medals & 2 & 2.6 \\
\hline & I enter the classroom with positive energy and attitude & 1 & 1.3 \\
\hline & I reward them with out-of-classroom education (at their homes), albeit rarely & 1 & 1.3 \\
\hline & Total & 4 & 5.2 \\
\hline & Grand Total & 77 & 100 \\
\hline
\end{tabular}

The teachers expressed the instructional applications they conducted to make the classroom an entertaining environment as doing-living (31.2\%), auditory (26\%), audiovisual $(20.8 \%)$, visual $(9.1 \%)$, intellectual $(5.2 \%)$, psychological (5.2\%) and general (2.6) applications.

\subsubsection{The Teacher Views on the Photograph(s) of the Classrooms Where They Wanted to Instruct the Courses}

Table 10. Distribution of teachers based on the photograph(s) of the classrooms where they wanted to instruct

\begin{tabular}{ccc}
\hline & $\begin{array}{c}\text { The number of teachers who wanted to instruct in } \\
\text { the classroom depicted in the photograph (f) }\end{array}$ & $\begin{array}{c}\text { The percentage of teachers who wanted to instruct in } \\
\text { the classroom depicted in the photograph (\%) }\end{array}$ \\
\hline $\begin{array}{c}\text { Photo 1 (Finland) } \\
\text { Photo 2 (USA) }\end{array}$ & 8 & 80 \\
Photo 3 (Finland/Technological \\
$\quad \begin{array}{c}\text { Classroom) } \\
\text { Total }\end{array}$
\end{tabular}

The classroom that the teachers liked the most (80\%) was the Finnish classroom. This was followed by the other Finnish (technological) classroom photograph (20\%). In general, no teacher liked the photograph of the American classroom. Furthermore, the findings demonstrated that the teachers who liked the first Finnish classroom photograph were mostly public school teachers, while the other photograph (technological classroom) was liked only by private school teachers. 


\subsubsection{The Views of Teachers on the Classroom Environments Depicted in the Photographs}

Table 11. Teacher views on the Finnish classroom depicted in photo 1

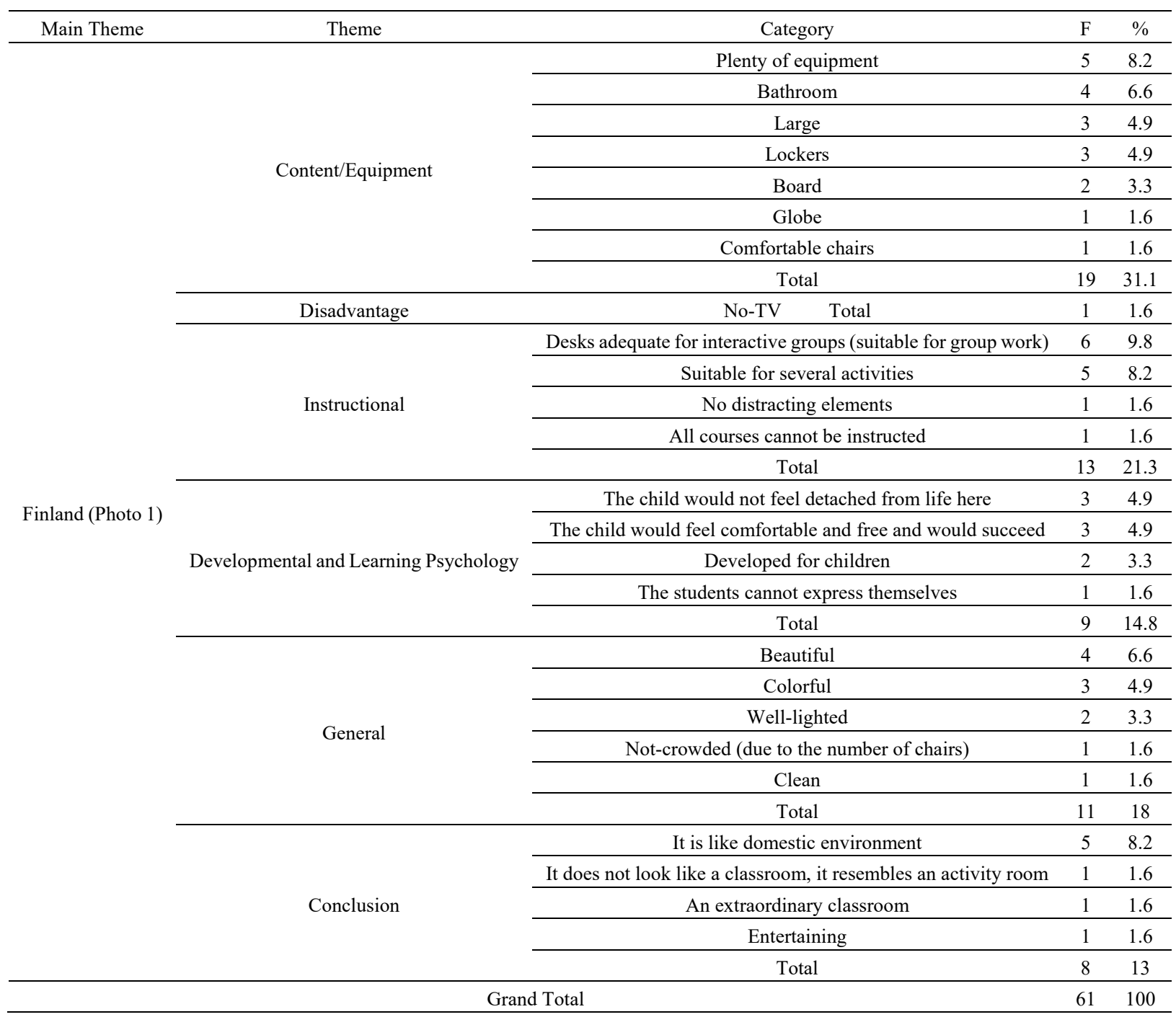

The teachers explained their views about the first photograph taken in Finland by stating that there was plenty of equipment $(31.1 \%)$ and there was a bathroom. Teachers explained their views in the instructional dimension $(21.3 \%)$ by stating that the layout was suitable for interactive groups (suitable for group work) and high number of activities. Teachers explained their views in general dimension (18\%) by stating that the classroom was beautiful and colorful, and in the developmental and learning psychology dimension (14.8\%) by stating that here, the child does not feel detached, and feels comfortable, free and succeeds, and in the conclusion dimension (13\%), they stated that the classroom was similar to the domestic environment, and stated that there was no TV in the disadvantages dimension.

Table 12. Teacher views on the American classroom depicted in photo 2

\begin{tabular}{|c|c|c|c|c|}
\hline Main Theme & Theme & Category & $\mathrm{F}$ & $\%$ \\
\hline \multirow{5}{*}{$\begin{array}{l}\text { USA (Photo } \\
\text { 2) }\end{array}$} & \multirow{5}{*}{ Content/Equipment } & Delineascope & 2 & 6.4 \\
\hline & & TV & 2 & 6.4 \\
\hline & & Microphone (it is good like a conference hall) & 2 & 6.4 \\
\hline & & Chairs, two children do not share a desk like in our classes & 2 & 6.4 \\
\hline & & Large & 1 & 3.2 \\
\hline
\end{tabular}




\begin{tabular}{|c|c|c|c|}
\hline & Large board & 1 & 3.2 \\
\hline & Computer & 1 & 3.2 \\
\hline & Flag & 1 & 3.2 \\
\hline & Pencil holders on desks for everyone to share & 1 & 3.2 \\
\hline & Air conditioning system on the ceiling & 1 & 3.2 \\
\hline & Total & 14 & 45.2 \\
\hline \multirow{4}{*}{ Disadvantages } & No smart board & 1 & 3.2 \\
\hline & TV is old and non-technological & 1 & 3.2 \\
\hline & U-Shaped sitting organization would have been better & 1 & 3.2 \\
\hline & Total & 3 & 9.7 \\
\hline Instructional & $\begin{array}{l}\text { Those who are not seated towards the board may not actively participate } \\
\text { in the course }\end{array}$ & 1 & 3.2 \\
\hline \multirow{4}{*}{$\begin{array}{l}\text { Developmental and Learning } \\
\text { Psychology }\end{array}$} & $\begin{array}{l}\text { The students cannot individually express themselves (due to the sitting } \\
\text { arrangement) }\end{array}$ & 1 & 3.2 \\
\hline & It is not adequate for primary school student level & 1 & 3.2 \\
\hline & Suitable for group work & 1 & 3.2 \\
\hline & Total & 3 & 9.7 \\
\hline \multirow{4}{*}{ General } & Low ceiling & 1 & 3.2 \\
\hline & Orderly & 1 & 3.2 \\
\hline & Desks are clean & 1 & 3.2 \\
\hline & Total & 3 & 9.7 \\
\hline \multirow{4}{*}{ Conclusion } & It looks like our classrooms & 4 & 12.9 \\
\hline & A cold-official environment & 2 & 6.4 \\
\hline & A monotonous classroom & 1 & 3.2 \\
\hline & Total & 7 & 22.6 \\
\hline & Grand Total & 31 & 100 \\
\hline
\end{tabular}

The teachers explained their views about the second photograph taken in the USA by stating that there was a delineascope and there is a TV in the content/equipment dimension (45.2\%). Teachers explained their views in the conclusion dimension (22.6\%) by stating that it looks like our classrooms and the environment was cold and official. Teachers explained their views in the developmental and learning psychology dimension (9.7\%) by stating that it was not suitable for primary school level, in general dimension $(9.7 \%)$ by stating that the classroom had low ceiling and it was orderly, and in the disadvantages dimension (9.7\%), they stated that there was no smartboard in the classroom and the TV was old and non-technological, and stated that those who do not see the board could not actively participate in the course (due to the sitting arrangement) in the instructional dimension $(3.2 \%)$.

Table 13. Teacher views on the Finnish classroom (technological) depicted in photo 3

\begin{tabular}{|c|c|c|c|c|}
\hline Main Theme & Theme & Category & $\mathrm{F}$ & $\%$ \\
\hline \multirow{13}{*}{$\begin{array}{l}\text { Finland/Technological Classroom } \\
\text { (Photo 3) }\end{array}$} & \multirow{3}{*}{ Content/Equipment } & There is a computer on each desk & 2 & 5 \\
\hline & & Large & 1 & 2.5 \\
\hline & & Total & 3 & 7.5 \\
\hline & \multirow{5}{*}{ Disadvantages } & The class is inadequate for the use of different methods & 3 & 7.5 \\
\hline & & The walls are colorless (no activities) & 2 & 5 \\
\hline & & There is only technology & 1 & 2.5 \\
\hline & & No lockers & 1 & 2.5 \\
\hline & & Total & 7 & 17.5 \\
\hline & \multirow{4}{*}{ Instructional } & $\begin{array}{l}\text { The desks are suitable for both group and individual } \\
\text { work }\end{array}$ & 3 & 7.5 \\
\hline & & $\begin{array}{l}\text { Research could be conducted and students could Access } \\
\text { everything they are interested at once }\end{array}$ & 1 & 2.5 \\
\hline & & Computers may lead to laziness among students & 1 & 2.5 \\
\hline & & Total & 5 & 12.5 \\
\hline & Developmental and Learning & Unsuitable for socialization & 1 & 2.5 \\
\hline
\end{tabular}




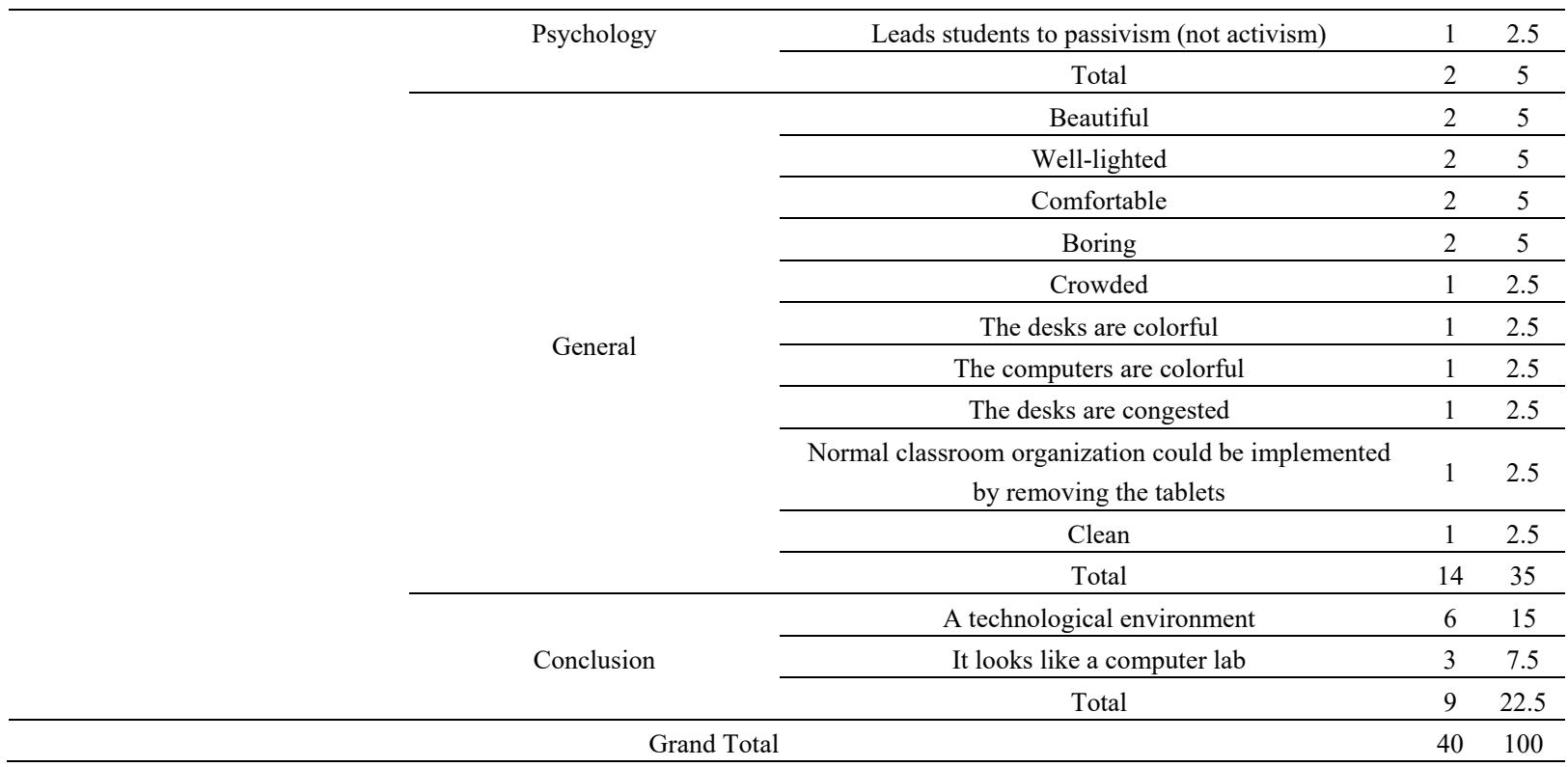

The teachers explained their views about the third photograph taken in Finland (technological classroom) by stating that it was beautiful, well-lighted and comfortable in the general dimension (35\%). Teachers explained their views in the conclusion dimension (22.5\%) by stating that it was a technological environment. Teachers explained their views in the disadvantages (17.5\%) by stating that the class was not suitable to use different methods, in instructional dimension $(12.5 \%$ ) by stating that the desks were suitable for both group and individual work, and in content/equipment dimension (7.5\%), they stated that there was a computer on every desk, and stated that the class was not suitable for socialization and leads students to passivism in time in the developmental and learning psychology dimension (5\%).

\subsection{Findings Obtained with the Interviews Conducted with the Students}

In this sub-section, the findings on the views of the students on whether their classrooms were entertaining or boring during the learning process, an entertaining classroom environment, and a boring classroom environment are included. Furthermore, the findings related to the views of the students on the efforts of their teachers to make the classroom an entertaining environment, whether they desired to be instructed in the classrooms depicted in the photographs, and on the classroom environment depicted in the photographs are also included in this section.

\subsubsection{The Student Views on Whether Their Classroom Was Entertaining or Boring in the Education Process}

Table 14. General student views on whether their classroom was entertaining or boring

\begin{tabular}{lcc}
\hline Main Themes & F & $\%$ \\
\hline Sometimes entertaining, sometimes boring & 55 & 68.75 \\
Entertaining & 25 & 31.25 \\
Boring & - & 0 \\
Total & 80 & 100 \\
\hline
\end{tabular}

Majority of the students (68.75\%) considered that their classes were sometimes entertaining, sometimes boring. A minority $(31.25 \%)$ considered that their classes were entertaining. Furthermore, none of the students considered that their schools were generally boring.

Table 15. The views of the students which implied that their class was entertaining

\begin{tabular}{llccc}
\hline Main Theme & Theme & Category & F & $\%$ \\
\hline \multirow{4}{*}{ Entertaining } & Sharing & We study the lessons with our peers & 2 & 8 \\
\cline { 2 - 5 } & \multirow{2}{*}{ Equipment } & We have a library & 2 & 8 \\
\cline { 2 - 5 } & & We have lockers & 2 \\
\hline
\end{tabular}




\begin{tabular}{|c|c|c|c|}
\hline & We have material & 1 & 4 \\
\hline & We have a smart board & 1 & 4 \\
\hline & We have a large classroom & 1 & 4 \\
\hline & We have a board & 1 & 4 \\
\hline & Total & 10 & 32 \\
\hline \multirow{6}{*}{ Instruction } & We play games during class & 6 & 24 \\
\hline & We conduct entertaining activities & 3 & 12 \\
\hline & We glue the activities we develop on the board & 1 & 4 \\
\hline & The teacher allows us to watch videos related to the course & 1 & 4 \\
\hline & Sometimes, the teacher draws funny images on the board, and we laugh & 1 & 4 \\
\hline & Total & 12 & 48 \\
\hline \multirow{4}{*}{ General } & Our teacher is like a family member, an affectionate person & 1 & 4 \\
\hline & Our teachers entertain us & 1 & 4 \\
\hline & I am happy when I learn something new & 1 & 4 \\
\hline & Total & 3 & 12 \\
\hline & Grand Total & 25 & 100 \\
\hline
\end{tabular}

The students argued that their classroom environment was entertaining within the context of instruction (48\%), equipment (32\%), general (12\%), and sharing ( $8 \%$ ) dimensions.

Table 16. The views of the students which implied that their class was boring

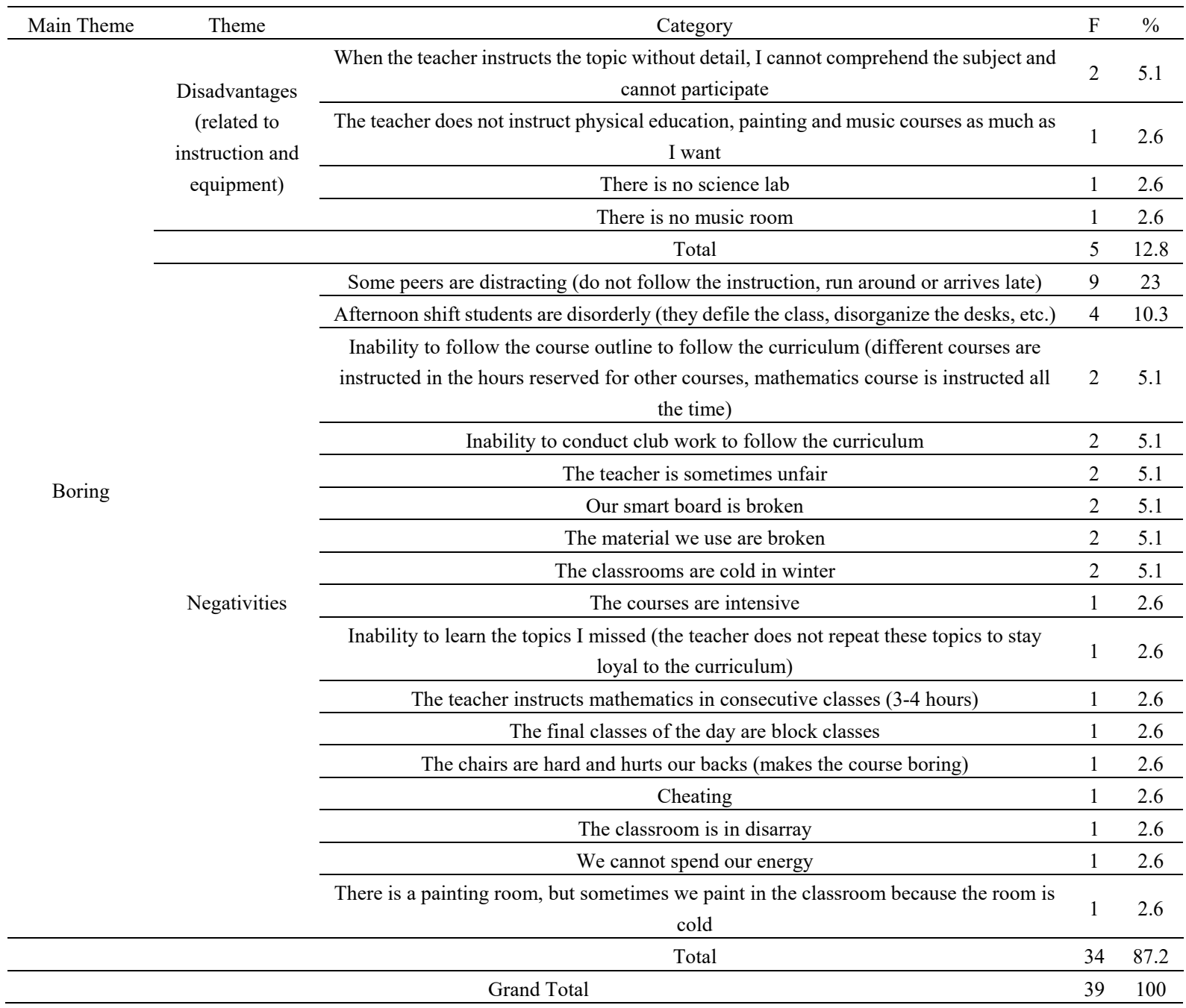


The views of the students that implied that their classrooms were boring were categorized under negativities $(87.2 \%)$ and disadvantages $(12.8 \%)$ dimensions.

\subsubsection{The Views of Students on Entertaining and Boring Classroom Environment}

Table 17. The views of students on entertaining classroom environment

\begin{tabular}{|c|c|c|c|c|}
\hline Main Theme & Theme & Category & $\mathrm{F}$ & $\%$ \\
\hline & \multirow{5}{*}{$\begin{array}{l}\text { With respect to instructional } \\
\text { applications }\end{array}$} & If we conduct applied (educational) activities & 4 & 13.2 \\
\hline & & $\begin{array}{l}\text { If professionals related to the course topic could be invited to } \\
\text { the class }\end{array}$ & 1 & 3.3 \\
\hline & & If the teacher is very "good" & 1 & 3.3 \\
\hline & & If the brakes are longer & 1 & 3.3 \\
\hline & & When we participate in the course & 1 & 3.3 \\
\hline & & & 8 & 26.4 \\
\hline \multirow{8}{*}{$\begin{array}{l}\text { Entertaining classroom } \\
\quad \text { environment }\end{array}$} & \multirow{8}{*}{ With respect to the environment } & $\begin{array}{l}\text { If we could use the labs more frequently (if we conduct } \\
\text { experiments) }\end{array}$ & 2 & 6.6 \\
\hline & & If the classroom is larger & 1 & 3.3 \\
\hline & & If the classes are orderly & 1 & 3.3 \\
\hline & & $\begin{array}{l}\text { If everyone has a private classroom (implementation of } \\
\text { individual education from time to time) }\end{array}$ & 1 & 3.3 \\
\hline & & If we could use the music room frequently & 1 & 3.3 \\
\hline & & If we could use the painting room frequently & 1 & 3.3 \\
\hline & & If the instruction is conducted in the garden & 1 & 3.3 \\
\hline & & $\begin{array}{l}\text { If there is a slide on the windows and we could slide down to } \\
\text { the garden }\end{array}$ & 1 & 3.3 \\
\hline \multicolumn{3}{|c|}{ Total } & 9 & 30 \\
\hline & \multirow{10}{*}{$\begin{array}{l}\text { With respect to } \\
\text { material/equipment }\end{array}$} & If we have chairs instead of desks & 2 & 6.6 \\
\hline & & If there are beds & 2 & 6.6 \\
\hline & & If there are armchairs/sofas & 2 & 6.6 \\
\hline & & If there are plenty of boards & 1 & 3.3 \\
\hline & & If there are tablets on the desks & 1 & 3.3 \\
\hline & & If the music room material are not missing & 1 & 3.3 \\
\hline & & If the painting room material are not missing & 1 & 3.3 \\
\hline & & If the lab material are not missing & 1 & 3.3 \\
\hline & & If the lockers are larger & 1 & 3.3 \\
\hline & & If the lockers are not broken & 1 & 3.3 \\
\hline \multicolumn{3}{|c|}{ Total } & 13 & 43.3 \\
\hline \multicolumn{3}{|c|}{ Grand Total } & 30 & 100 \\
\hline
\end{tabular}

The views of the students about an entertaining classroom environment were categorized based on material/equipment (43.3\%), environment (30\%) and instructional applications $(26.4 \%)$.

Table 18. The views of students on boring classroom environment

\begin{tabular}{|c|c|c|c|c|}
\hline Main Theme & Theme & Category & $\mathrm{F}$ & $\%$ \\
\hline & \multirow{7}{*}{$\begin{array}{l}\text { With } \\
\text { respect to } \\
\text { instruction }\end{array}$} & If we only study the course without entertainment (without games 4 , without painting 1 ) & 5 & 9.1 \\
\hline & & If the teacher does not instruct the course well & 3 & 5.5 \\
\hline & & If the teacher only instructs and we listen & 3 & 5.5 \\
\hline & & If the instruction is rapid without allowing us to comprehend the topic & 2 & 3.6 \\
\hline & & If there are no activities in the class & 2 & 3.6 \\
\hline & & If we write all the time & 1 & 1.8 \\
\hline & & $\begin{array}{l}\text { When boring courses are instructed all the time (for example, when there is no physical } \\
\text { education) }\end{array}$ & 1 & 1.8 \\
\hline & & Total & 17 & 30.9 \\
\hline
\end{tabular}




\begin{tabular}{|c|c|c|c|c|}
\hline & $\begin{array}{c}\text { With } \\
\text { respect to } \\
\text { material/eq } \\
\text { uipment }\end{array}$ & When the material are old or broken & 1 & 1.8 \\
\hline & & Total & 1 & 1.8 \\
\hline \multirow{6}{*}{$\begin{array}{c}\text { Boring } \\
\text { classroom } \\
\text { environment }\end{array}$} & \multirow{6}{*}{$\begin{array}{c}\text { With } \\
\text { respect to } \\
\text { the } \\
\text { environmen } \\
\text { t }\end{array}$} & When there is too much noise & 7 & 12.7 \\
\hline & & If the classroom is disorderly & 5 & 9.1 \\
\hline & & If the classroom is not clean & 4 & 7.3 \\
\hline & & If the classroom is cold & 2 & 3.6 \\
\hline & & If the classroom is too hot & 1 & 1.8 \\
\hline & & When it gets dark, because we become sleepy and it is boring & 1 & 1.8 \\
\hline & & Total & 20 & 36.4 \\
\hline & \multirow{8}{*}{$\begin{array}{l}\text { With } \\
\text { respect to } \\
\text { psychology }\end{array}$} & When there is no participation in the class & 5 & 9.1 \\
\hline & & If we do not get along well with our peers & 4 & 7.3 \\
\hline & & When there are rude students in the class & 2 & 3.6 \\
\hline & & When it is never my turn to speak & 2 & 3.6 \\
\hline & & If we are under pressure & 1 & 1.8 \\
\hline & & When the teachers takes a hard line & 1 & 1.8 \\
\hline & & When there is no sharing among peers & 1 & 1.8 \\
\hline & & When teacher behaves differently to the students (then, there is injustice) & 1 & 1.8 \\
\hline \multicolumn{3}{|r|}{ Total } & 17 & 30.9 \\
\hline \multicolumn{3}{|r|}{ Grand Total } & 55 & 100 \\
\hline
\end{tabular}

The views of the students about a boring classroom environment were categorized based on environmental (36.4\%), instructional (30.9\%), psychological (30.9\%), and equipment (1.8\%) dimensions.

\subsubsection{The Views of Students on the Efforts of the Teachers to Make the Classroom Environment Entertaining}

Table 19. The views of students on the efforts of the teachers to make the classroom environment entertaining

\begin{tabular}{|c|c|c|c|c|}
\hline Main Theme & Theme & Category & $\mathrm{F}$ & $\%$ \\
\hline & \multirow{9}{*}{$\begin{array}{l}\text { With respect to instructional } \\
\text { techniques }\end{array}$} & Theatre/drama & 7 & 14 \\
\hline & & $\begin{array}{l}\text { Instructs the courses with games and in an } \\
\text { entertaining manner }\end{array}$ & 7 & 14 \\
\hline & & Asks entertaining questions & 2 & 4 \\
\hline & & Debates & 1 & 2 \\
\hline & & Storifies the topics & 1 & 2 \\
\hline & & Does not make us to write too much & 1 & 2 \\
\hline & & Organizes trips to museums & 1 & 2 \\
\hline & & Organizes trips to villages & 1 & 2 \\
\hline & & Asks riddles at class & 1 & 2 \\
\hline & Total & & 22 & 44 \\
\hline \multirow{5}{*}{$\begin{array}{l}\text { The teachers do the following to make the } \\
\text { class more entertaining }\end{array}$} & \multirow{5}{*}{$\begin{array}{l}\text { With respect to instructional } \\
\text { activities }\end{array}$} & Makes us read books & 3 & 6 \\
\hline & & Makes us conduct experiments & 2 & 4 \\
\hline & & Makes us do potato prints in painting class & 2 & 4 \\
\hline & & We make compass in painting class & 1 & 2 \\
\hline & & We conduct tree planting activities & 1 & 2 \\
\hline & Total & & 9 & 18 \\
\hline & $\begin{array}{c}\text { With respect to } \\
\text { material/equipment }\end{array}$ & Uses the smart board & 1 & 2 \\
\hline & Total & & 1 & 2 \\
\hline & \multirow{3}{*}{ With respect to psychology } & $\begin{array}{l}\text { Allows us to watch movies (with corn or fries) in } \\
\text { the class }\end{array}$ & 4 & 8 \\
\hline & & Makes jokes & 2 & 4 \\
\hline & & Approaches us like a relative & 2 & 4 \\
\hline
\end{tabular}




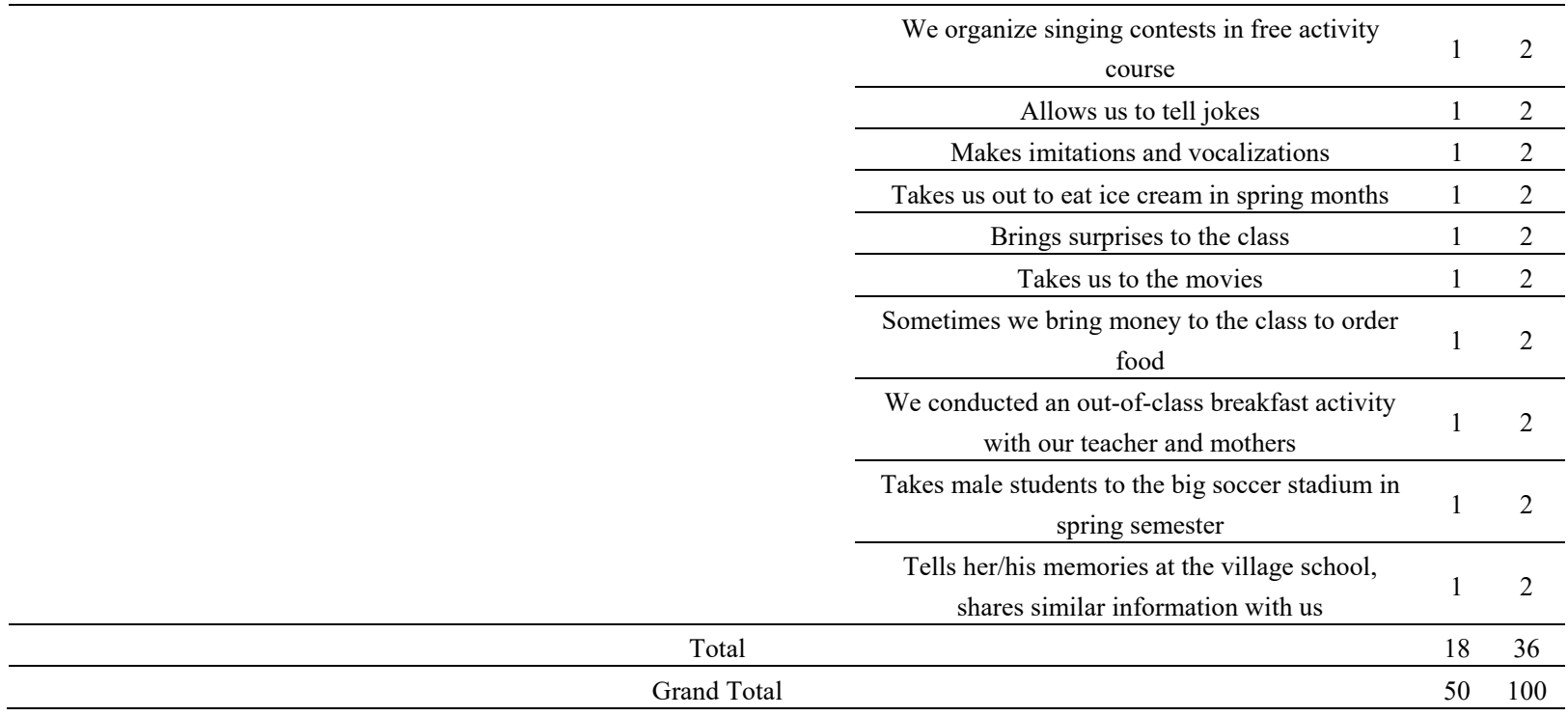

The views of the students on the practices of their teachers that they might like were categorized based on instructional techniques (44\%), psychological (36\%), instructional activities (18\%) and equipment (2\%) dimensions.

3.2.4 The Views of Students on Whether They Wanted to Study in the Classroom Environments Depicted in the Photographs

Table 20. Distribution of students based on the photograph(s) of the classrooms where they wanted to be instructed

\begin{tabular}{ccc} 
& $\begin{array}{c}\text { The number of students who wanted to be instructed } \\
\text { in the classroom depicted in the photograph (f) }\end{array}$ & $\begin{array}{c}\text { The percentage of students who wanted to be } \\
\text { instructed in the classroom depicted in the photograph } \\
\text { (\%) }\end{array}$ \\
\hline $\begin{array}{c}\text { Photo 1 (Ivory Coast) } \\
\text { Photo 2 (Finland) } \\
\text { Photo 3 }\end{array}$ & - & - \\
(Finland/technological class) \\
Total
\end{tabular}

Among the classrooms depicted in the photographs, the classroom that the students desired to be instructed (similar to the teachers) was the classroom in Finland (71.3\%). This was followed by the Finnish technological classroom (28.7\%) (also similar to the teachers). In general, no students liked the classroom photograph taken in the Ivory Coast and did not want to study there. Furthermore, it was observed that the students who liked both Finnish classrooms were mostly public school students.

\subsubsection{The Views of Students on the Classroom Environment Depicted in Photographs}

Table 21. The views of students about the Ivory Coast classroom environment depicted in photo 1

\begin{tabular}{|c|c|c|c|c|}
\hline $\begin{array}{c}\text { Main } \\
\text { Theme }\end{array}$ & Theme & Category & $\mathrm{F}$ & $\%$ \\
\hline \multirow{8}{*}{$\begin{array}{c}\text { Photo } 1 \\
\text { (Ivory } \\
\text { Coast) }\end{array}$} & \multirow{8}{*}{ Disadvantages } & The desks are not processed nor polished, they look old & 26 & 18.1 \\
\hline & & Lacks required material & 5 & 3.5 \\
\hline & & No lockers & 4 & 2.8 \\
\hline & & No boards & 2 & 1.4 \\
\hline & & There are no pictures/activities on the walls & 2 & 1.4 \\
\hline & & They would be cold in winter, there is no glass on windows & 2 & 1.4 \\
\hline & & No curtains & 1 & 0.7 \\
\hline & & No entertainment corner & 1 & 0.7 \\
\hline
\end{tabular}




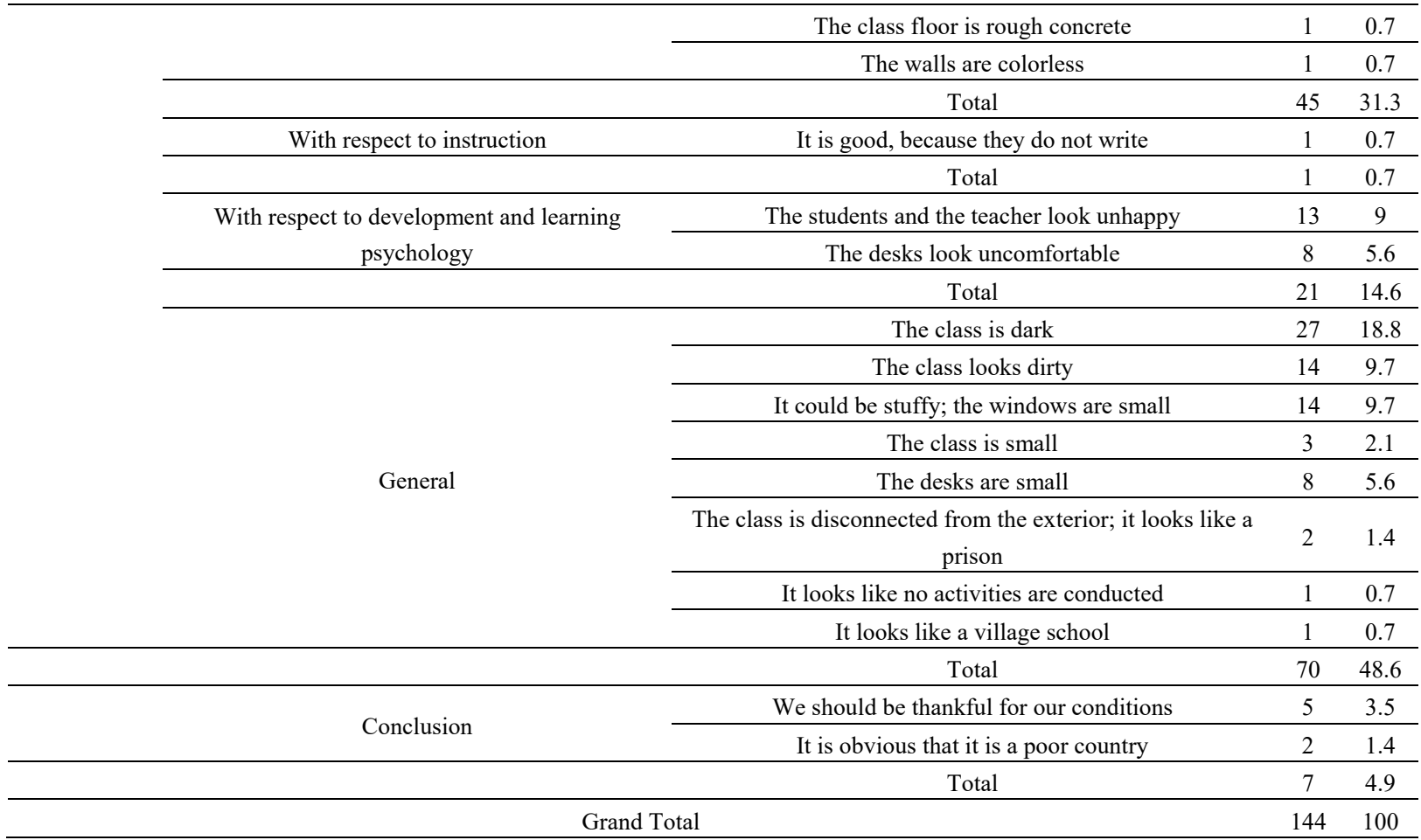

The views of the students on the photograph of the Ivory Coast classroom were scrutinized under the dimensions of general (48.6\%), disadvantages (31.3), developmental and learning psychology (14.6\%), conclusion (4.9\%) and instructional $(0.7 \%)$.

Table 22. The views of students about the Finnish classroom environment depicted in photo 2

\begin{tabular}{|c|c|c|c|c|}
\hline Main Theme & Theme & Category & $\mathrm{F}$ & $\%$ \\
\hline \multirow{23}{*}{$\begin{array}{l}\text { Photo } 2 \\
\text { (Finland) }\end{array}$} & \multirow{12}{*}{ With respect to content/equipment } & It is full of activity material & 9 & 4.7 \\
\hline & & Aquarium & 8 & 4.1 \\
\hline & & Comfortable chairs & 8 & 4.1 \\
\hline & & Lockers & 4 & 2.1 \\
\hline & & Boards & 4 & 2.1 \\
\hline & & Accessible globe & 4 & 2.1 \\
\hline & & Plenty of desks & 3 & 1.6 \\
\hline & & Bathroom & 2 & 1 \\
\hline & & Toys & 2 & 1 \\
\hline & & Books & 2 & 1 \\
\hline & & Computer & 1 & 0.5 \\
\hline & & Recycle bin & 1 & 0.5 \\
\hline & & Total & 48 & 24.9 \\
\hline & \multirow{6}{*}{ With respect to instruction } & Several activities are conducted & 22 & 11.4 \\
\hline & & Some activities are exhibited on the wall & 4 & 2.1 \\
\hline & & $\begin{array}{l}\text { Desks are beautiful, round; we sit on rows, we cannot see the } \\
\text { board }\end{array}$ & 4 & 2.1 \\
\hline & & Suitable for active instruction & 1 & 0.5 \\
\hline & & It looks like the activities are different & 1 & 0.5 \\
\hline & & Total & 32 & 16.6 \\
\hline & \multirow{4}{*}{$\begin{array}{l}\text { With respect to development and learning } \\
\text { psychology }\end{array}$} & The class has contact with nature & 5 & 2.6 \\
\hline & & Suitable for high peer interaction & 3 & 1.6 \\
\hline & & Organized for children & 2 & 1 \\
\hline & & The students would feel energetic in this environment & 1 & 0.5 \\
\hline
\end{tabular}




\begin{tabular}{|c|c|c|c|}
\hline & The students would feel happy in this environment & 1 & 0.5 \\
\hline & Total & 12 & 6.2 \\
\hline \multirow{8}{*}{ General } & Spacious, pleasant, well-lighted & 16 & 8.3 \\
\hline & $\begin{array}{l}\text { An orderly classroom (it does not look like double shift } \\
\text { schooling, therefore it is orderly) }\end{array}$ & 13 & 6.7 \\
\hline & A clean classroom & 11 & 5.7 \\
\hline & A colorful classroom & 8 & 4.1 \\
\hline & A large classroom & 6 & 3.1 \\
\hline & It looks like a preschool classroom & 2 & 1 \\
\hline & The environment is suitable for social activities & 1 & 0.5 \\
\hline & Total & 57 & 29.5 \\
\hline \multirow{10}{*}{ Conclusion } & A beautiful classroom & 20 & 10.4 \\
\hline & An entertaining classroom & 8 & 4.1 \\
\hline & I wish it was my classroom & 5 & 2.6 \\
\hline & It is obviously a rich country & 4 & 2.1 \\
\hline & It is a nice environment for children & 2 & 1 \\
\hline & There, the students should be hardworking & 2 & 1 \\
\hline & It looks like our classroom a bit & 1 & 0.5 \\
\hline & It looks like a domestic environment & 1 & 0.5 \\
\hline & I would participate in the course more there & 1 & 0.5 \\
\hline & Total & 44 & 22.8 \\
\hline \multicolumn{2}{|c|}{ Grand Total } & 193 & 100 \\
\hline
\end{tabular}

The students liked the Finnish classroom the most and their views were discussed under general (29.5\%), content/equipment (24.9\%), conclusion (22.8\%), instructional (16.6\%), and development and learning psychology $(6.2 \%)$ dimensions.

Table 23. The views of students about the Finnish classroom environment (technological) depicted in photo 3

\begin{tabular}{|c|c|c|c|c|}
\hline Main Theme & Theme & Category & $\mathrm{F}$ & $\%$ \\
\hline \multirow{23}{*}{$\begin{array}{l}\text { Photo } 3 \text { Finland/Technological } \\
\text { Classroom }\end{array}$} & \multirow{6}{*}{$\begin{array}{l}\text { With respect to } \\
\text { content/equipment }\end{array}$} & Everyone has a computer & 26 & 14.1 \\
\hline & & Smart board & 16 & 8.6 \\
\hline & & Large classroom & 4 & 2.2 \\
\hline & & $\begin{array}{l}\text { The windows are wide and several, thus more fresh air } \\
\text { enters the class }\end{array}$ & 2 & 1.1 \\
\hline & & The floor is hardwood (nice) & 1 & 0.5 \\
\hline & & Total & 49 & 26.5 \\
\hline & \multirow{5}{*}{ Disadvantages } & The walls are & 2 & 1.1 \\
\hline & & No lockers & 1 & 0.5 \\
\hline & & No board & 1 & 0.5 \\
\hline & & Teacher's desk is small (impractical) & 1 & 0.5 \\
\hline & & Total & 5 & 2.7 \\
\hline & \multirow{6}{*}{ With respect to instruction } & Students can sit in groups or alone in the desks & 7 & 3.8 \\
\hline & & All courses could be instructed on computers & 2 & 1.1 \\
\hline & & Advanced activities and research could be conducted & 2 & 1.1 \\
\hline & & More activities could be conducted & 2 & 1.1 \\
\hline & & Students would not try to write quickly there & 1 & 0.5 \\
\hline & & Total & 14 & 7.6 \\
\hline & \multirow{6}{*}{ General } & The classroom is well-lighted & 18 & 9.7 \\
\hline & & The desks are colored & 18 & 9.7 \\
\hline & & The classroom is clean & 13 & 7 \\
\hline & & The classroom is orderly & 12 & 6.5 \\
\hline & & The classroom is beautiful & 10 & 5.4 \\
\hline & & The desks are triangular & 7 & 3.8 \\
\hline
\end{tabular}




\begin{tabular}{|c|c|c|c|}
\hline & The computers are colorful & 4 & 2.2 \\
\hline & $\begin{array}{l}\text { The courses can be instructed very nicely (effectively) } \\
\text { there }\end{array}$ & 3 & 1.6 \\
\hline & The desk size is adequate & 2 & 1.1 \\
\hline & The desks look like they are tall & 1 & 0.5 \\
\hline & Total & 88 & 47.6 \\
\hline & $\begin{array}{l}\text { This is a technological environment, it is ideal in my } \\
\text { opinion }\end{array}$ & 12 & 6.5 \\
\hline & $\begin{array}{l}\text { The children's eyesight may deteriorate, because they } \\
\text { would always sit across the tablets }\end{array}$ & 4 & 2.2 \\
\hline & Computers emit radiation, it is an unhealthy classroom & 4 & 2.2 \\
\hline Conclusion & I wish our classroom was like that & 3 & 1.6 \\
\hline & $\begin{array}{l}\text { It is a technological classroom, because it looks like a rich } \\
\text { country }\end{array}$ & 2 & 1.1 \\
\hline & I would not want to leave that environment & 2 & 1.1 \\
\hline & It hardly looks like our classes & 1 & 0.5 \\
\hline & No need to carry a bag & 1 & 0.5 \\
\hline \multicolumn{2}{|c|}{ Total } & 29 & 15.7 \\
\hline \multicolumn{2}{|c|}{ Grand Total } & 185 & 100 \\
\hline
\end{tabular}

The views of the students on the other Finnish classroom (technological) photograph that they liked were discussed under the themes of general $(47.6 \%)$, content/equipment $(26.5 \%)$, conclusion $(15.7 \%)$, instructional (7.6\%) and disadvantages (2.7\%).

\section{Discussion, Conclusion and Recommendations}

\subsection{Discussion and Conclusion}

Based on the study findings, it can be suggested that the views of the teachers and the students on whether the classroom was entertaining or boring in the learning process were similar in several aspects. Most teachers stated that their classes were sometimes entertaining, sometimes boring; most students similarly stated that their classes were sometimes entertaining, sometimes boring. However, while only a small section of the teachers stated that their classroom was boring, it was observed that no student clearly stated that their classes were boring. The fact that no students found their classroom boring and most of the teachers did not find their classrooms boring could be interpreted as positive. In a study by Sakai and Kikuchi (2009) on the topic, it was reported that most students argued that their teachers considered the classroom boring and even their teachers were boring. However, it was reported that when the students find the classroom boring and they do find it uninteresting, they could not learn adequately (Ara, 2009, p. 162).

It was observed that the entertainment in classroom was associated with the theme of instruction by both the teachers and the students. Furthermore, it was observed that the teachers explained the entertainment in classrooms in the student participation category and the students explained the same within instructions mostly included games category. On student participation in the classroom, it was reported that students are motivated in the classes of teachers who act close (Gecer \& Deryakulu, 2004; Rocca, 2004), interested in their problems (Fontana, 1985, cited by Gurbetoglu \& Tomakin, 2011), and they act more relaxes and participated more and as a result, achieved more. It was also reported that the acceptance and sincerity of the teacher enforced the pleasure of the students in the learning process (Al-Shara, 2015, p.160). While emphasizing the importance of game playing in learning, it was stated that games were among the most effective tools that make it entertaining and help children to learn with joy (Ara, 2009, p. 166). In fact, it was observed that technology-based learning that includes virtual media and digital games is a transformative approach to education beyond the incentives to develop teacher training (Chu, Angello, Saenz, \& Quek, 2017). In the study by Duran and Kaplan (2014), where "comprehension with a word" game developed with mathematical concepts for mathematics course, it was determined that most students expressed positive views about the game and that they enjoyed the game. And to what extent the game should be included in the teaching process requires the teacher to plan according to the relevant situation and subject.

It was observed that teachers explained the conditions where the classroom was boring mostly in the theme of student and the students explained the same mostly in the theme of negativities. Furthermore, it was observed that the teachers explained the boredom in their classrooms mostly in the category of no participation in the class and the students explained the same mostly in the category of peer distraction. The factor of peer distraction stated as 
the reason for a boring by the students in the present study was stated as a significant problem by teachers in another study (Yoleri, Bitir, Kara, \& Atli, 2018). In the study, it was observed that among the most frequently observed problem behavior, the teachers mentioned students moving around in way to distract their peers, bothering students sitting behind or front of them, and whispering or talking secretly and not following the instruction in the class. When we look at this issue in reverse, in a study on attention deficit (Gunay, 2006, p.41), bothering and distracting peers was explained by boredom in classroom, not as a reason for boredom in the classroom. In the study, it was reported that students with attention deficit could exhibit behavior that may distract peers and disturb the peace in class, such as talking, snipe at peers and making strange sounds. The important point to be considered is the awareness of the students with attention deficit and situations that could lead to attention deficit in the classroom and to take necessary measures to prevent it.

It was observed that the students explained entertaining classroom design in the context of the environment theme, while students explained the same in the material/equipment theme. Furthermore, the teachers explained an entertaining classroom design in the categories of a comfortable environment and "it should include required material (tools)" the most, and students often explained the same in "if we conduct applied (educational) activities," "if we could use the labs (conduct experiments) frequently," "if we had chairs instead of desks," "if we had beds," and "if we had armchairs/sofas" categories. In the study by Sakai \& Kikuchi (2009, p.60), the presence of inadequate or uninteresting material in the classroom was categorized among factors that prevent motivation based on the previous studies on in-classroom motivation. In a study by Gorham and Christophel's (1992), it was observed that participants considered logistical factors such as "inadequate material" (36\%) among the factors that hampered motivation. Therefore, based on these data, it can be suggested that presence of adequate material in the classroom leads to motivation, the presence of inadequate or insufficient material, on the other hand, prevents learning motivation. In a study by Kalayci (2005, p. 178), similar to the findings of the present study, it was observed that the students included the factor of not using the lab in science course among the problems they perceived about the instruction methods of their teachers.

It was observed that teachers mostly explained how a boring classroom environment could be under the "teacher-oriented" theme, while students explained it in the environment dimension. Furthermore, it was determined that teachers considered boring classroom environment in "when there is no participation," "teacher-oriented instruction," "lack of material/equipment," and "when the class is crowded" categories, and students considered the same in "when there is a lot of noise in the classroom," "when only the course is instructed without entertainment (without games, painting)," and "when there is no participation" categories. In a study by Akbaba-Altun (2009, p. 571), where the reasons of academic failure among primary school students were investigated, it was concluded that most students complained about boring and monotonous instruction by the teachers and parents complained about learn-by-rote educational approach of the teachers. In another study (Kalayci, 2005, p. 178), it was also concluded that the students perceived the fact that their teachers did not to listen to them and ignored their desires as problems related to the instruction of the teacher in the classroom. In the study by Akbaba-Altun (2009, p. 571), it was determined that students considered noisy and crowded classroom environment and parents considered crowded classes among the reasons for students' academic failure. In a study by Karsi (2012), it was stated that crowded and noisy classes could lead to problems such as disorientation of the teacher and the student and could lead to undesired behavior in the classroom and apathy and daydreaming in the classroom.

The physical and visual applications that teachers conducted were considered mostly in "I provide comfort," and in "I adjust the classroom temperature and lighting to adequate levels," "each student has own locker," "we have a library," "we utilize the board." Categories by the teachers, while the visual applications were considered in "by doing-living" theme and mostly in "playing games," "watching movies/videos," "telling jokes," and "humor" categories. Certain previous studies indicated the importance and benefit of adequate temperature and lighting in learning environments (Akbaba \& Turhan, 2016; Karsi, 2012; Kunkul, 2008). In the present study, it was observed that the participants approached the same issue from a different perspective and teachers stated that they make the class comfortable in terms of temperature and lighting in order to make the classroom entertaining. Furthermore, the fact that teachers kept material and equipment such as lockers, library and boards in the classroom to make the class more entertaining could be considered as an interesting finding. Because, this demonstrated that based on the teacher perceptions, a comfortable classroom that contains adequate material and equipment was necessary for the students to consider the class entertaining. The finding that the teachers stated that instructionally, watching movies/videos, telling jokes created an entertaining environment was supported by other studies in the literature (Butun-Kar \& Elma, 2017; Celik, 2014; Kaya \& Cengelci, 2011; Martin, 2008; Ozkan \& Gevenc, 2017; Saracaloglu, Gundogdu, Celik, \& Altin, 2013). 
It was observed that students considered the efforts of their teachers to make the classroom more entertaining in the instructional techniques theme and in the categories of "theater/drama" and "instruction with games". There are studies in the literature that supported this finding (Ebner \& Holzinger, 2007; Ellington, Gordon, \& Fowlie, 1998; Korucu \& Kurtlu, 2016). In the literature, there are also studies that supported the student view that playing theater/drama in the classroom makes the class more entertaining (Arslan \& Gursoy, 2008; Coban \& Cecen, 2013; Sagirli \& Gurdal, 2002; Yalcinkaya, 2010).

In terms of the most admired classroom photograph, both the teachers and the students liked the classroom in Finland (with blue seats), followed by the other Finnish (technological) classroom. In other words, teachers did not want to instruct in the American classroom and students did not want to be instructed in the Ivory Coast classroom. This could be due to the fact that both these images lacked color and activities. On this issue, H. D. Arslan (2010) stated that user desires should be taken into consideration in classroom design to increase learning motivation in quality classroom environments and learning would be easier and permanent in a study conducted with students, classroom teachers and pre-service architects.

It was also determined that the teachers who liked the first Finnish classroom photograph were mostly public school teachers, while the private school teachers preferred the other photograph (technological class). Furthermore, it was also found that students who liked both Finnish classroom photographs were mostly public school students. This could be due to the fact that the number of public school students was higher in the present study.

Teachers have expressed their views in the context of content/equipment theme and the category of "plenty of tools and equipment" about the Finnish classroom (Photo 1) that they liked the most. This was followed by instruction theme and "desk layout is for interactive groups" and "plenty of activities are conducted" categories, the general theme and "beautiful" category, the theme of development and learning psychology, "here, the child would not feel disconnected from life" and result theme, "it is like a domestic environment" category.

Teachers expressed their views on the second most favorite Finnish/Technological classroom (Photo 3) mostly in the general theme and "beautiful," "well-lighted," "a comfortable environment," and "boring" categories. This was followed by the conclusion theme, "a technological environment" category, disadvantages theme, "the class is not adequate for the use of different methods" category, instruction theme, "the desks are adequate for both group and individual work" category, content/equipment theme, "there is a computer on each desk" category, and finally development and learning psychology theme and "not suitable for socialization" and "leads students to passivism in time" categories.

For the American classroom, which they did not, teachers expressed views mostly in content/equipment theme, "there is a delineascope," "there is a TV," "there is a microfone (it is beautiful like a conference hall)," and "there are chairs and two pupils do not share a desk like in our classes" categories. This was followed by the conclusion theme and "it looks like our classes" category.

Students mostly expressed their views about the Finnish classroom (Photo 2) that they liked the most in the general theme and "it is spacious, pleasant and well-lighted classroom" category. This was followed by the content/equipment theme, "it is full of activity material" category, conclusion theme, "it is a very nice classroom" category, instruction theme, "plenty of activities are conducted" category, developmental and learning psychology theme, "class is in touch with nature" category.

The students mostly expressed views on the second most favorite Finnish/Technological classroom (Photo 3) in the general theme and "the classroom is well-lighted" and "the desks are colorful" categories. This was followed by content/equipment theme, "everyone has a computer" category, conclusion theme, "this is a technological environment; it is ideal in my opinion" category, instruction theme, "the desks are suitable for both group and individual work" category, and disadvantages theme, "the walls are very plain" category.

The students expressed views on the Ivory Coast classroom that they did not like mostly in general theme, "the classroom is dark" category. This was followed by disadvantages theme, "the desks are not processes and varnished; they look old" category, developmental and learning psychology theme, "the students and the teacher look unhappy" category, conclusion theme, "we should be thankful" category, and instruction theme, "it is nice since the students do not write" category.

Both teachers' and the students' favorite classroom was the same Finnish classroom, and both teachers and students stated that the classroom contained plenty of material/equipment, several activities could be conducted, and it was a beautiful classroom. Also, the second most favorite classroom for both the teachers and the students was Finland/Technological classroom and they stated that the classroom was well-lighted, included a computer on 
each desk, it was a technological environment and it was ideal and beautiful, and the desks were adequate for both group and individual work.

Comments about the photographs demonstrated that both teachers and students liked classrooms with plenty of material and equipment, adequate temperature and lighting, several colors, abundant activities and technological equipment. And they criticized the classrooms they did not like due to the inadequacy of the classroom to utilize different methods, its resemblance to their classrooms, or the fact that they were dark, old-looking and the students and teachers looked unhappy.

\subsection{Recommendations}

Based on the study findings, the following could be recommended for educational politicians, program developers, Ministry of National Education (MoNE) officials, school administrators and teachers:

- The schools and classrooms, where instruction takes place and the students spend long hours should be well-equipped as technological, psychological and physical and qualified to take the psychological, instructional and developmental needs of the teachers and students into account,

- The programs should be more adequate in temporal and instructional aspects based on the developmental characteristics of the students and should entertain the students,

- School administrators should provide order both in the school and the classroom and should make the environment more spacious, practical and entertaining,

- The teachers should be empathetic and sympathetic to the students, and

- The teachers should include several entertaining activities such as games, humor and music in learning-teaching processes.

\section{References}

Akbaba, A., \& Turhan, M. (2016). Investigating teachers' views about physical problems of primary schools (Van sample). KTÜ Institute of Social Science Journal of Social Science, 6(12), 341-357.

Akbaba-Altun, S. (2009). An investigation of teachers', parents', and students' opinions on elementary students' academic failure. Elementary Education Online, 8(2), 567-586.

Akengin, H., \& Ibrahimoglu, Z. (2010). Effects of use of cartoons in social studies course on students' academic achievement and their opinions about the course. Ondokuz Mayis University Journal of Education Faculty, 29(2), 1-19.

Akınoglu, O. (2004). Constructivist learning and geography teaching. International Journal of Geography and Geography Education, 10, 73-94.

Al-shara, İ. (2015). Learning and teaching between enjoyment and boredom as realized by the students: A survey from the educational field. European Scientific Journal, 11(19), 146-168.

Ara, S. (2009). Use of songs, rhymes and games in teaching English to young learners in Bangladesh. The Dhaka University Journal of Linguistics, 2(3), 161-172. https://doi.org/10.3329/dujl.v2i3.4150

Arai, K. (2004). What 'demotivates' language learners?: Qualitative study on demotivational factors and learners' reactions. Bulletin of Toyo Gakuen University, 12, 39-47.

Arslan, H. D. (2010). Assessment of the perception-linked parameters in primary school classroom design and the recommendations on their design (Unpublished doctoral dissertation). University of Selçuk, Konya, Turkey.

Arslan, M., \& Gursoy, A. (2008). Establishing motivation in teaching Turkish as a second language through role playing and dramatic activities. Ege Journal of Education, 9(2), 109-124.

Asilioglu, B. (2013). The meaning of humor and its role in education. Journal of Bayburt Üniversitesi Faculty of Education, Educational Philosophy Special Issue-I, 208-243. Retrieved from https://www.academia.edu/25076789/Bayburt_\%C3\%9Cniversitesi_E\%C4\%9Fitim_Fak\%C3\%BCltesi_De rgisi

Ay, Y., Acat, M. B., \& Yuksel, I. (2016). Qualitative investigation of teacher, administrator, and expert views on improvement of primary school curriculum leisure time activities. Turkish Studies-International Periodical for the Languages, Literature and History of Turkish or Turkic, 11(3), 371-388. https://doi.org/10.7827/TurkishStudies.9316 
Aydin, A., Bakirci, H., \& Urey, M. (2012). Opinions of classroom teachers about free activity studies course. Journal of National Education, 193, 214-230. Retrieved from https://dhgm.meb.gov.tr/yayimlar/dergiler/Milli_Egitim_Dergisi/193.pdf

Baba-Khouya, Y. (2018). Students Demotivating Factors in the EFL classroom: The Case of Morocco. Advances in Language and Literary Studies, 9(2), 150-159. https://doi.org/10.7575/aiac.alls.v.9n.2p.150

Bakhsh, S. A. (2016). Using games as a tool in teaching vocabulary to young learners. English Language Teaching, 9(7), 120-128. https://doi.org/10.5539/elt.v9n7p120

Barata, G., Gama, S., Jorge, J., \& Goncalves, D. (2013). Engaging engineering students with gamification. In 5th International Conference on Games and Virtual Worlds for Serious Applications (pp. 1-8). https://doi.org/10.1109/VS-GAMES.2013.6624228

Bektas, M., \& Dincer, Ş. (2011). Opinions of elementary school teachers on free activity lesson. 10th National Elementary School Teachers' Training Symposium (5-7 May), Sivas, Turkey: Cumhuriyet University. Retrieved from https://www.pegem.net/Akademi/sempozyumbildiri_detay.aspx?id=122480

Bloom, B. S. (1976). Human characteristics and school learning. New York: McGraw-HiII Book Company.

Bozpolat, E. (2016). Teachers' perceptions on free activities course in primary schools. ZfWT, 8(2), 217-239.

Brewer, R., Anthony, L., Brown, Q., Irwin, G., Nias, J., \& Tate, B. (2013). Using gamification to motivate children to complete empirical studies in lab environments. In Proceedings of the 12th International Conference on Interaction Design and Children, 388-391. ACM. https://doi.org/10.1145/2485760.2485816

Bryant, J., Comisky, P. W., Crane, J. S., \& Zillmann, D. (1980). Relationship between college teachers' use of humor in the classroom and students' evaluations of their teachers. Journal of Educational Psychology, 72(4), 511-519. https://doi.org/10.1037/0022-0663.72.4.511

Butun-Kar, E., \& Elma, C. (2017). The effects of media-supported education on academic success and permanence of learning in social studies course. Mersin University Journal of the Faculty of Education, 13(2), 531-549. https://doi.org/10.17860/mersinefd.336740

Cakir, V. (2005). Entertainment and television as a social event (Example of Konya). Journal of Selçuk University Institutes of Social Sciences, 13, 123-142.

Campbell, T. A. (2012). Digital storytelling in an elementary classroom: Going beyond entertainment. Social and Behavioral Sciences, 69, 385-393. https://doi.org/10.1016/j.sbspro.2012.11.424

Caponetto, I., Earp, J., \& Ott, M. (2014). Gamification and education: A literature review. In C. Busch (Ed.), Proceeding of ECGBL2014-8th European Conference on Games Based Learning, Vol 1, 9-10 October, Berlin/Germany.

Cekmez, E., Yildiz, C., \& Butuner, S. Ö. (2012). Phenomenographic Research Method. Necatibey Faculty of Education Electronic Journal of Science and Mathematics Education, 6(2), 77-102.

Celik, B. (2014). The effect of using humour and concept cartoons on students' achievement, attitude, anxiety and retention in 9th grade ict lesson (Unpublished Master's Thesis). University of Adnan Menderes Aydin, Turkey.

Chabeli, M. (2008). Humor: A pedagogical tool to promote learning. Curationis, 31(3), 51-59. https://doi.org/10.4102/curationis.v31i3.1039

Chang, C., Warden, C. A., Liang, C., \& Lin, G. (2018). Effects of digital game-based learning on achievement, flow and overall cognitive load. Australasian Journal of Educational Technology, 34(4), 155-167. https://doi.org/10.14742/ajet.2961

Chu, S. L., Angello, G., Saenz, M., \& Quek, F. (2017). Fun in making: Understanding the experience of fun and learning through curriculum-based making in the elementary school classroom. Entertainment Computing, 18, 31-40. https://doi.org/10.1016/j.entcom.2016.08.007

Coban, A., \& Cecen, M. A. (2013). The perceptions of Turkish preservice teachers regarding drama practices. Journal of Theory and Practice in Education, 9(4), 334-353.

Cornett, C. E. (1986). Learning through laughter: Humor in the classroom. Retrieved from http://files.eric.ed.gov/fulltext/ED276028.pdf

Crouch, C. H., Fagen, A. P., Callan, J. P., \& Mazur, E. (2004). Classroom demonstrations: Learning tools or entertainment? American Journal of Physics, 72(6), 835-838. https://doi.org/10.1119/1.1707018 
Delpech, R. (2002). Why are school students bored with science? Journal of Biological Education, 36(4) 156-157. https://doi.org/10.1080/00219266.2002.9655825

Dickey, M. D. (2011). Murder on Grimm Isle: The impact of game narrative design in an educational game-based learning environment. British Journal of Educational Technology, 42(3), 456-469. https://doi.org/10.1111/j.1467-8535.2009.01032.x

Dundar, H., \& Karaca, E. T. (2011). Assesment of leisure time actvities lesson in primary school. Erzincan University Journal of Education Faculty, 13(2), 105-121.

Duran, M., \& Kaplan, A. (2014). Review of students-teachers relating to "from word to notion" game developed with mathematical purviews. Journal of Kırşehir Faculty of Education (JKEF), 15(2), 155-173.

Ebner, M., \& Holzinger, A. (2007). Successful implementation of user-centered game based learning in higher education: An example from civil engineering. Computers \& Education, 49, 873-890. https://doi.org/10.1016/j.compedu.2005.11.026

EIN-Education Information Network. (2018). We learn with fun. Retrieved from http://www.eba.gov.tr/arama?q=e $\% \mathrm{C} 4 \% 9$ Flenerek $\% 20 \% \mathrm{C} 3 \% \mathrm{~B} 6 \% \mathrm{C} 4 \% 9$ Frenme

Elias, M. J. (2015). Using humor in the classroom. Retrieved from http://www.edutopia.org/blog/using-humor-in-the-classroom-maurice-elias?utm_source=facebook\&utm_me dium=post\&utm_campaign=blog-using-humor-in-the-classroom-july-link-repost

Ellington, H., Gordon, M., \& Fowlie, J. (1998). Using games and simulations in the classroom. London: Kogan Page.

Erdal, G. G. (2012). The place of music teaching methods in pre-school education according to the theorists of development and learning. International Journal of New Trends in Arts, Sports \& Science Education (IJTASE), 1(4), 54-59.

Erdem, E. (2015). The effect of enriched learning environment on mathematical reasoning and attitude (Unpublished doctoral dissertation). University of Atatürk, Erzurum, Turkey.

Ersoy, A. F. (2016). Social studies teachers' and students' perception of the citizenship and democracy education

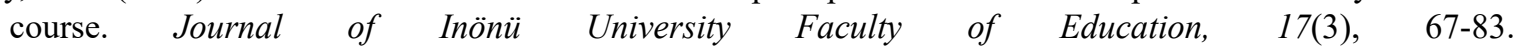
http://dx.doi.org/10.17679/iuefd.17345163

Ferahoglu, N. S., Tepecik, A., \& Kalyoncu, R. (2014). A study on the effects of practicing Tokat kerchief patterns in the original printing activities in the 8th grades of primary schools. Journal of Bayburt University Faculty of Education, 9(2), 182-192.

Gecer, A., \& Deryakulu, D. (2004). The effect of teacher immediacy on students; Success, attitude and motivation. Educational Administration: Theory and Practice, 40, 518-543.

Gencel-Ataman, Ö. (2014). The effect of Mozart's music on the success of middle school students in mathematics courses. Journal of Hacettepe University Faculty of Education, 29(2), 81-93.

Gocer, A. (2010). Benefiting from refined literary texts to create a multi stimulant learning environment for Turkish language teaching. TÜBAR, XXVII, 341-369.

Goehle, G. (2013). Gamification and web-based homework. Primus, 23(3), 234-246. https://doi.org/10.1080/10511970.2012.736451

Gorham, J., \& Christophel, D. (1992). Students' perception of teacher behaviors as motivating and demotivating factors in college classes. Communication Quarterly, 40, 239-252. https://doi.org/10.1080/01463379209369839

Guler, H. K., Cakmak, D., \& Kavak, N. (2013). Effects of Mathematics Teaching with Cartoons on Students' Academic Achievements and Attitudes. Journal of Uludağ University Faculty of Education, 26(1), 149-160.

Gultekin, M., Atalay, N., \& Ay, Y. (2014) Primary teacher and student opinions regarding leisure activities at primary education. Kastamonu Education Journal, 22(2), 419-437.

Gunay, Ş. (2006). Lifelong experience of attention deficit and hyperactivity disorder. Sapiens Journal of Special Education and Rehabilitation, 2(5), 40-46. Retrieved from https://www.ruzgarterapi.com/wp-content/uploads/PDF/sapiens-sayi-4.pdf

Gurbetoğlu, A., \& Tomakin, E. (2011). An analysis of students' views of liked and disliked teacher behaviours. Journal of Ahi Evran University Faculty of Education, 12(1), 261-276. 
Heathcote, D., \& Bolton, G. (1994). Drama for learning: Dorothy Heathcote's mantle of the expert approach to education (Dimensions of drama series). Portsmouth: Heinemann.

Huang, Y., Liu, M., Lai, C., \& Liu, C. (2017). Using humorous images to lighten the learning experience through questioning in class. British Journal of Educational Technology, 48(3), 878-896. https://doi.org/10.1111/bjet.12459

Kalayci, N. (2005). Which situations do the elementary school students perceive as problems at their schools? Educational Administration: Theory and Practice, 11(2), 167-193.

Kalyoncu, R., \& Liman, S. (2013). Teachers' metaphors about "fine arts lesson" and "fine arts teacher". NWSA-Fine Arts, 8(1), 115-130.

Kapp, K. M. (2012). The gamification of learning and instruction: Game-based methods and strategies for training and education. San Francisco: John Wiley \& Sons. https://doi.org/10.1145/2207270.2211316

Karsi, F. (2012). The Relationship Between Highschool Students' Perceptions of Classroom Athmosphere and Their Academic Achievement (Unpublished master's thesis). University of Dokuz Eylul, Izmir, Turkey.

Kaya, E., \& Cengelci, T. (2011). Pre-service teachers' opinions regarding using films in social studies education. Journal of Social Studies Education Research, 2(1), 116-135.

Kaya, S. (2011). Teachers' and Students' Views on the Use of Humor in Art Education as a Teaching Strategy (Unpublished master's thesis). University of Gazi, Ankara, Turkey.

Kim, S., Song, K., Lockee, B., \& Burton, J. (2018). Gamification in learning and education-enjoy learning like gaming. USA: Springer, Cham. https://doi.org/10.1007/978-3-319-47283-6

Koca-Ozgun, A. S., \& Sen, A. I. (2006). Reasons of secondary school students' negative attitudes towards mathematics and science courses. Eurasian Journal of Educational Research, 23, 137-147.

Korucu, S., \& Kurtlu, Y. (2016). Opinions and recommendations of Turkish teachers regarding the use of games and toys in Turkish courses as educational materials. Turkish Studies International Periodical for the Languages, Literature and History of Turkish or Turkic, 11(9), 539-558.

Kunkul, T. (2008). The analysis of the relationship between students' participation level of classroom activities and classroom atmosphere (Unpublished master's thesis). University of Cukurova, Adana, Turkey.

Learning with Fun. (2018). Retrieved from https://learningwithfun.net/

Mann, S., \& Robinson, A. (2009). Boredom in the lecture theatre: An investigation into the contributors, moderators and outcomes of boredom amongst university students. British Educational Research Journal, 35(2), 243-258. https://doi.org/10.1080/01411920802042911

Martin, R. A. (2008). The psychology of humor: An integrative approach. Elsevier Books, London.

Memnun, D., \& Akkaya, R. (2010). Seventh grade students' opinions about the Mathematics course. Journal of Theoretical Educational Science, 3(2), 100-117.

Miles, M. B., \& Huberman, A. M. (1994). Qualitative data analysis: An expanded sourcebook (2nd ed.). California: SAGE Publications.

Ozdemir, S. (2001). Total quality management in education. Manas Journal of Social Studies, 1(2), 253-270. Retrieved from http://journals.manas.edu.kg/mjsr/oldarchives/Vol01_Issue02_2001/217.pdf

Ozkan, H. I. (2008). The effect of understanding of humor in teacher and student on class atmosphere (Unpublished master's thesis). University of Selcuk, Konya, Turkey. Retrieved from http://acikerisimarsiv.selcuk.edu.tr:8080/xmlui/bitstream/handle/123456789/9275/211367.pdf?sequence=1 \&isAllowed $=\mathrm{y}$

Ozkan, S., \& Gevenc, S. (2017). The effect of using jokes in the teaching of history subjects in social studies lesson on academic achievement. Education and Society in the 21st Century, 6(17), 315-333.

Ozturk, D., Peker, A., \& Gokdas, Y. (2017). Visual arts course through the eyes of gifted students: Case of Bayburt. Gumushane University Electronic Journal of the Institute of Social Sciences, 8(19), 114-127. https://doi.org/10.17823/gusb.334

Prokop, P., Prokop, M., \& Tunnicliffe, S. D. (2007). Is biology boring? Student attitudes toward biology. Journal of Biological Education, 42(1), 36-39. https://doi.org/10.1080/00219266.2007.9656105

Quina, J. (1989). Effective secondary teaching: Going beyond the bell curve. New York: Harper and Row. 
Raymer, R. (2011). Gamification: using game mechanics to enhance eLearning. eLearn Magazine, 9(3). https://doi.org/10.1145/2025356.2031772

Rocca, K. A. (2004). College student attendance: Impact of instructor immediacy and verbal aggression. Communication Education, 53(2), 185-195. https://doi.org/10.1080/03634520410001682447

Sagirli, H. E., \& Gurdal, A. (2002). The effect of drama technique on student attitude in science class. 5th National Congress of Science and Mathematics Education, 16-18 October. Ankara, Turkey: ODTÜ. Retrieved from http://www.fedu.metu.edu.tr/ufbmek-5/ozetler/d086.pdf

Sakai, H., \& Kikuchi, K. (2009). An analysis of demotivators in the EFL classroom. System, 37, 57-69. https://doi.org/10.1016/j.system.2008.09.005

Saracaloglu, A. S., Gundoğdu, K., Celik, B., \& Altin, M. (2013). Humor in education and training. Adnan Menderes University Faculty of Education Journal of Education Sciences, 4(1), 10-22.

Sidekli, S., Er, H., Yavaser, R., \& Aydin. E. (2014). An alternative method in social studies education: Cartoon. International Journal of Turkish Education Sciences, 2(2), 151-163.

Stupiansky, W., Stupiansky, S., \& Nicholas, G. (1999). Games that teach. Instructor Primary, 108(5).

Teach Thought. (2017). 8 tips for integrating pop culture in the classroom. Retrieved from https://www.teachthought.com/pedagogy/8-tips-for-integrating-pop-culture-in-the-classroom/

Tezel-Sahin, F., Balci, A., Aydin-Kilic, Z. N., \& Yazar, A. (2015). An analysis on the opinions of mothers who live in the city center and the rural area about their children's play and toys: (The sample of Erzurum). Journal of Research in Education and Teaching, 4(4), 298-311.

TLI-Turkish Language Institution. (2015). Entertainment. Retrieved from http://tdk.gov.tr/

Tranter, J. (2004). Biology: dull, lifeless and boring? Journal of Biological Education, 38(3), 104-105. https://doi.org/10.1080/00219266.2004.9655914

Tural, H. (2005). The Effects of Teaching Mathematics in Elemantary School by Games and Activities on Achievement and Attitude (Unpublished master's thesis). University of Dokuz Eylül, İzmir, Turkey.

Turan-Guntepe, E., \& Donmez-Usta, N. (2017). Game-based learning. In H. F. Odabaş1, B. Akkoyunlu, \& A. İşman (Eds.), Eğitim teknolojileri okumaları 2017 (pp. 917-932)。 Ankara: TOJET-Sakarya University.

Uygun, M. (2011). Using of photo-based narrative as a qualitative research method in consumer research. Journal of Consumer and Consumption Research, 3(1), 29-64.

Vernon, S. (2009). The benefits of using games. Retrieved from http://www.englishgames.com

Wagner, E., \& Urios-Aparisi, E. (2011). The use of humor in the foreign language classroom: Funny and effective? Humor-International Journal of Humor Research, 24(4), 399-434. https://doi.org/10.1515/humr.2011.024

Witt, P., Wheeless, L., \& Allen, M. (2004). A meta-analytical review of the relationship between teacher immediacy and student learning. Communication Monographs, 71, 184-207. https://doi.org/10.1080/036452042000228054

Yalcinkaya, E. (2010). Students opinions related to the drama method used in social studies lesson. Millî Eğitim, $186,278-290$.

Yildirim, İ. (2016). Development, implementation and evaluation of a gamification based curriculum for the lesson of 'teaching principles and methods' (Unpublished doctorate thesis). University of Gaziantep, Gaziantep, Turkey.

Yoleri, S., Bitir, T., Kara, M., \& Atli, Y. (2018). Determination of the undesirable student behaviors observed by the first grade primary school teachers in their classrooms. Journal of Human Sciences, 15(4), 2602-2613. https://doi.org/10.14687/jhs.v15i4.4676

\section{Copyrights}

Copyright for this article is retained by the author(s), with first publication rights granted to the journal.

This is an open-access article distributed under the terms and conditions of the Creative Commons Attribution license (http://creativecommons.org/licenses/by/4.0/). 